\title{
Marine and nonmarine deposition in a long-term low-accommodation setting: an example from the Middle Pleistocene Qm2 Unit, eastern Central Italy
}

Claudio Di Celma*, Luca Ragaini**, Mauro Caffau***

*Scuola di Scienze e Tecnologie, Università di Camerino, 62032 Camerino, Italy;

**Dipartimento di Scienze della Terra, Università di Pisa, 56126 Pisa, Italy

***OGS (Istituto Nazionale di Oceanografia e di Geofisica Sperimentale), 34010 Sgonico (TS), Italy

Corresponding author: claudio.dicelma@unicam.it

ragaini@unipi.it

mcaffau@ogs.trieste.it

\begin{abstract}
Facies anatomy and large-scale stratigraphic organization of mid-Pleistocene strata (Qm2 Unit) exposed near the town of Ortona, eastern central Italy, have been defined through an integrated outcrop and subsurface dataset, and record sedimentation within a long-term low-accommodation setting. The studied interval can be subdivided into nine facies associations, reflecting a range of continental, marginal marine, nearshore and innermost shelf environments, and contains a wellpreserved record of high-frequency relative sea-level changes in the form of a stack of three unconformity-bounded sequences. Each of the three sequences, designated Qm2 2 , Qm2 2 , and Qm2 from oldest to youngest, consists of a specific subset of the nine identified facies associations as a function of preserved depositional systems and systems tracts. Typically, the following architectural elements occur in ascending stratigraphic order: i) a basal unconformity, molded by fluvial incision and subaerial exposure during sea-level fall and shoreface erosion during subsequent rise; ii) a maximum regressive surface, which is coincident with the sequence boundary; iii) a transgressive systems tract including braided-river conglomerates and floodplain fines within the confines of an incised-valley, palustrine carbonates and back-barrier lagoon mudstones, and a deepening- and fining-upward shoreface to offshore-transition facies succession bounded at the base by a wave ravinement surface; iv) a sharp regressive surface of marine erosion produced by shoreface incision during relative sea-level fall; and v) a prograding, downstepping, and offlapping sharp-based lithofacies assemblage of either beach conglomerates or sandstones, ascribed to the falling stage systems tract, overlain by a rooted paleosol marking subaerial exposure.
\end{abstract}


Sequences were deposited on the uplifting palaeo-Adriatic shelf in response to repeated highfrequency and high-amplitude eustatic changes in sea level that would promote the creation of accommodation space. By subtracting space to deposition, the contemporaneous regional uplift of the basin margin may be accounted for the shingled, downstepping configuration of individual sequences to form a falling stage sequence set of a larger composite sequence. In dip view, the erosional contact at the base of the Qm2 falling stage sequence set is a composite regressive surface, resulting from the downdip convergence and amalgamation of multiple erosional surfaces produced by the progressive basinward translation of successive sequences. Results from this study have direct implications for the oil and gas field development and exploration when making predictions of reservoir and seal geometries within shallow-marine, marginal-marine, and nonmarine sediments emplaced in similar long-term limited-accommodation settings.

Keywords: long-term limited accommodation, sequence stratigraphy, Middle Pleistocene

\section{Introduction}

Over the last two decades, a large number of outcrop-based studies has provided evidence of the cyclothemic character of fluvial, shallow-marine and off-shelf sedimentary successions deposited under icehouse climatic regimes and demonstrated that high-amplitude, Milankovitch-duration sealevel fluctuations would have been responsible for the pronounced cyclic arrangement. Examples of such icehouse sequences have been well-documented from Plio-Pleistocene successions in California, Japan, Italy, New Zealand and Ecuador (Clifton et al., 1988; Ito and Katsura, 1992; Kitamura et al., 1994; Rio et al., 1996; Milli, 1997; Naish et al., 1998; Cantalamessa et al., 2005; Benvenuti et al., 2007; Di Celma et al., 2005, 2015; Di Celma and Cantalamessa, 2012) from the Miocene of eastern USA, Chile and Ecuador (Kidwell, 1997; Di Celma and Cantalamessa, 2007; Cantalamessa et al., 2007), and from Permian strata in eastern Australia and South Africa (Fielding et al., 2006; Di Celma et al., 2011). Where these high-frequency eustatic changes in sea level took place against a background of third-order, tectonically driven sea-level changes, then composite sequences have been produced (e.g. Jones and Milton, 1994; Saul et al., 1999; McMurray and Gawthorpe, 2000; Pedersen et al., 2002; Zecchin et al., 2011). In particular, when accumulation occurred under long-term accommodation-limited conditions, unconformity bounded sequences show laterally and vertically complex stratigraphic stacking patterns and stratal characteristics that contrast markedly with those of sequences that accumulated in subsiding, high net-accommodation basins (e.g. Arnott et al., 2002; Allen and Fielding, 2007; Longhitano, 2008; Antia and Fielding, 2011; Antia et al., 2011). 
The mid-Pleistocene Qm2 Unit in eastern central Italy provides the possibility for a detailed characterization of the internal stratigraphy, bounding surfaces, and large-scale sequence architecture of shallow marine, marginal marine and nonmarine deposits laid down under longterm, net-accommodation-limited conditions promoted by the interplay between high-frequency, high-amplitude glacio-eustasy and background regional uplift. Under these circumstances, the major dictating factor on short-term changes in accommodation space were glacio-eustatic changes in sea level, whereas the long-term, progressive reduction in accommodation space was mainly controlled by regional uplift.

The primary objectives of this study include: i) to provide a detailed description and interpretation of facies associations commonly found in the study area in order to thoroughly indentify depositional systems in the Qm2 Unit; ii) to resolve the complex architecture of this long-term low accommodation unit by establishing a high-resolution sequence stratigraphic framework through the integration of the identified stratigraphic surfaces and lateral distribution and vertical development of intervening depositional systems. The results stemming from this study have significant applications to petroleum exploration and production, as well as for fluid (oil, water or gas) storage, in similar long-term limited accommodation settings and may contribute to the development and implementation of interpretative and predictive models for the nature and variability of subsurface reservoir equivalents.

\section{Geologic and stratigraphic setting}

The Pescara Basin is one of the Plio-Pleistocene depocentres of the Peri-Adriatic foredeep (Fig. 1), the last of a series of foreland systems developed from the Oligocene to the Neogene in front of the growing Apennines fold and thrust belt (e.g. Malinverno and Ryan, 1986; Ricci Lucchi, 1986; Doglioni, 1991; Argnani and Ricci Lucchi, 2001). The Pleistocene tectono-sedimentary evolution of the Pescara Basin is framed into a large-scale sequence-stratigraphic scheme (Cantalamessa et al., 1986; Ricci Lucchi, 1986). Specifically, within the traditional subdivision into Quaternary marine $(\mathrm{Qm})$ and Quaternary continental (Qc) unconformity-bounded stratigraphic units, regionally correlatable unconformities divide the upper portion of the basin fill into three major allogroups (Qm1, Qm2, and Qc from oldest to youngest). The unconformities separating these units, which record phases of basin reorganization linked to large-scale tectonics (e.g. Ori et al., 1991; Artoni, 2013; Bigi et al., 2013), are well recognizable along the basin margin and tend to become correlative conformities in a basinward direction. Allogroups record an overall regressive trend from slope and shelf mudstones (Qm1, Cantalamessa et al., 2009; Di Celma et al., 2010, 2013, 2016; Di Celma, 2011), through a series of sandstone-dominated high-frequency depositional 
sequences (Qm2, Cantalamessa and Di Celma, 2004), to conglomerate-dominated fluvial deposits (Qc, Bracone et al., 2012a; Di Celma et al., 2015). Due to the absence of age-diagnostic microfossils and deposits suitable for absolute age dating, the exact age of the Qm2 strata illustrated in this paper is difficult to constrain. However, based on paleomagnetic and biochronologic evidence, Agostini et al. (2007) dated the Qm2 Unit sediments exposed in the study area to the early Middle Pleistocene (MIS 19-17), just above the Matuyama/Bruhnes transition, which is placed at 0.781 Ma (Gradstein et al., 2004). Crudely equivalent sediments are exposed all along the eastern Apennine foothills, from Emilia Romagna in the north to Molise in the south, and the available age models suggest that they have been deposited during MIS 21-19 (Amorosi et al., 1998; Muttoni et al., 2011) or MIS 22-18 (Gunderson et al., 2014) in Emilia Romagna, and $900 \pm 100 \mathrm{ka}$ in central Marche (Cyr and Granger, 2008). Based on these ages, the studied succession was deposited during the 'Mid-Pleistocene Revolution' (ca.1.2-0.5 Ma), when low-amplitude, 41-ka obliquity-forced sea-level cycles of the earlier Pleistocene were replaced progressively in the later Pleistocene by high-amplitude 100-ka cycles with more extended glacial phases alternating with shorter interglacial phases (e.g. Mudelsee and Stattegger, 1997). In the study area (Fig. 2), the Qm2 Unit sedimentary succession is essentially undeformed with a regional northwesterly dip of less than $2^{\circ}$ and appears today above present sea-level due to smooth basin inversion resulting from uplift of the adjacent central Apennines since the upper part of the Early Pleistocene and the lower part of the Middle Pleistocene (e.g. D’Agostino et al., 2001; Bracone et al., 2012a). The average uplift rates calculated along the central Adriatic coast since then ranges between 0.8 and $1 \mathrm{~m} / \mathrm{ka}$ (Centamore and Nisio, 2003; Pizzi, 2003) and appear to increase inland.

\section{Study area, method and database}

The present study describes the Qm2 Unit stratigraphy exposed near the town of Ortona (eastern central Italy) between Lido di Riccio in the north and San Donato in the south (Fig. 2). In the northern area, from Lido di Riccio to Punta Lunga, Qm2 strata are exposed along coastal cliff sections that provide fresh, almost continuous lateral exposure. The detailed characterization of the exposed succession is based on sedimentologic, ichnologic and paleoecologic information gathered through detailed logging of twenty-six outcrop sections of different thickness. These sections were measured and described at centimetre to decimetre scale in order to capture depositional characteristics at the scale of individual sedimentary facies. The recorded attributes include grain size, bed thickness and configuration, physical sedimentary structures, body and trace fossil content, and bioturbation intensity (BI). Bioturbation intensity was estimated using a numerical ranking 
from 0 (no bioturbation) to 6 (complete bioturbation) following the guidelines of Taylor and Goldring (1993) and MacEachern et al. (2005). Correlation between measured sections was achieved by walking out beds along the outcrops. Where measuring sections or walking out beds was impossible along sheer cliffs, photomosaics were taken to facilitate correlation and mapping. Paleocurrent indicators were obtained by measuring orientations of ripple crests, trough axes, planar cross-bedding, and clast imbrication. Although the examined sections contain all transitions between the unconsolidated and consolidated rocks, for simplicity, the name of the rock in its consolidated state is used.

The large-scale architecture of the investigated sedimentary succession and facies trends within each component sequence have been reconstructed tracing bounding erosion surfaces initially observed in outcrop and later extended in the subsurface. Subsurface data consist of previously uninterpreted eleven cores from public and private sources drilled into the study interval over the past decades (Fig. 2). Eight of these cores are part of an extensive subsurface stratigraphic dataset carried out for the executive design of the double track variant of the Ancona-Bari railway (Chiocchini et al., 1994); two cores have been drilled for hydrogeologic investigations and are available for direct download from the publicly accessible site of the Istituto Superiore per la Protezione e Ricerca Ambientale (ISPRA, 2015); one lithological log was retrieved from a private source (A. Faraone 2014, personal communication). The closely spaced position of measured sections and cores permitted confident correlation of units and stratal surfaces. Outcrop and subsurface data have been incorporated into a perspective fence diagram forming the basis for the reconstruction of the lateral variations and vertical evolution of the Qm2 Unit across the entire study area (Fig. 3). Given the virtually undeformed nature of the studied succession, the present-day mean sea level has been used as a datum to hang cores and stratigraphic logs on the correlation panels. This choice of the datum surface is not ideal and implies that the resulting shoreline trajectory paths are slightly and systematically overestimated due to the very gentle syndepositional to postdepositional tectonic tilting to the northeast. Despite this, the basic stratal organization remains consistent and the cross-sections demonstrate and accurately depict stratal relationships and geometries observed in outcrop.

The systems tracts identified in the studied succession and their bounding surfaces have been indicated following the terminology proposed by Zecchin and Catuneanu (2013) for outcrop- and core-based high-resolution sequence stratigraphic studies. Accordingly, the sequence boundary is placed in correspondence of the end of the relative sea-level drop and, therefore, at the top of the falling stage systems tract (Plint and Nummedal, 2000). 


\section{Facies associations and environmental interpretation}

The nine facies associations (labelled FA-1 to FA-9) comprise the building blocks of the three Qm2 sequences described herein. Six of these facies associations (FA-1 through FA-6) are interpreted as being deposited in nearshore and inner-shelf settings, whereas three of them (FA-7 through FA-9) are inferred to represent deposition in marginal marine to nonmarine settings. These facies associations are described in detail below. Cantalamessa and Di Celma (2004), Amorosi et al. (2009) and Bracone et al. (2012b) provided a thorough account of roughly coeval strata exposed elsewhere in the basin.

\subsection{Facies Association 1 (FA-1): moderately to thoroughly bioturbated mudstones (offshore)}

Description. This facies association, which is the uppermost portion of the Qm1 Unit, is exposed in very limited outcrops along the sea-cliff but has commonly been encountered in wells drilled above and behind the coastal outcrops. It consists dominantly of blue-grey to light grey, thickly bedded, massive, thoroughly bioturbated mudstones (BI varies from 3 to 5) with sparse tabular layers of massive and normally graded silt and very fine-grained sand generally less than $1 \mathrm{~cm}$ thick. Fossil assemblages include marine molluscs, generally in life position, and abundant foraminifera and calcareous nannoplankton.

Interpretation. Textural features and high degree of bioturbation indicate that this facies association represents the lowest-energy conditions within the studied succession and that its deposition took place below the average storm wave base in an offshore environment away from sources of coarse sediment. Within this depositional setting, the silty and sandy layers are tempestites representing the sporadic distal incursions of coarser material from storms with magnitudes above the average. Based on the bathymetric range of the mollusc and benthic foraminifera assemblages, Ragaini et al. (2006) suggested an outer-shelf (upper bathyal-lower circalittoral) depositional setting. The abundance of body fossils and the intense bioturbation indicate hospitable bottom-water conditions, allowing epifaunal and infaunal organisms to thrive.

\subsection{Facies Association 2 (FA-2): bioturbated mudstones and fine-grained sandstones (offshore- transition)}

Description. The bulk of this facies association consists of intensely bioturbated (BI varies from 4 to 6) mudstones containing variable proportions of very thin (1-2 cm thick) intervening siltstone beds, showing rare diminutive oscillation ripple and current ripple laminae, and very fine- to finegrained sandstone beds characterized by low-angle, wavy parallel lamination and oscillatory ripple 
lamination (Fig. 4A). Mollusc shells are present but sparse and consist primarily of disarticulated bivalves found either dispersed throughout this facies or as small clumps. Apart from some little clumps of Ostrea edulis, characterizing faunal elements at the outcrop level are the infaunal species Panopea glycymeris, mainly preserved as conjoined individuals in vertical (life) or weak oblique position, and Glycymeris nummaria (=violacescens) preserved both as single and articulated valves. Sparse remains of Pinna sp. consist of single, very fragmented valves.

Interpretation. Grain size, sedimentary structures, amount of bioturbation, and macrofossil content indicate that this mudstone-rich facies association has been deposited between fair-weather and storm-wave base and reflects accumulation in an offshore-transition depositional environment. In this setting, the mud was derived as suspension load and accumulated during low-energy periods, whereas sand layers with ripple cross-lamination likely represent distal storm beds. Panopea glycymeris is a sedentary, deep-infaunal suspension-feeder living in sandy/silty grounds from the inner to outer shelf with preference for the shoreface zone (Marasti, 1991; Bernasconi and Robba, 1993). G. nummaria is a sedentary, very shallow-infaunal suspension-feeder that usually occurs in sandy bottoms of the inner and medium shelf. The different taphonomic attributes showed by $P$. glycymeris and G. nummaria, most specimens articulated and in life position (or just slightly dislodged) for the former and single and conjoined valves with different orientations for the latter, suggest the presence of rare events of physical disturbances able to exhume the shallow-infaunal forms (along with seminfaunal species such as Pinna sp.) but not having sufficient energy to exhume the deep-infaunal ones. The high degree of bioturbation observed in this facies association indicates that storm events were likely followed by long periods of low-energy conditions favouring the intense reworking of sediments.

\subsection{Facies Association 3 (FA-3): bioturbated massive sandstone (lower shoreface)}

Description. This facies association, attaining a maximum thickness of about $7 \mathrm{~m}$, consists of pervasively bioturbated, fine- to medium-grained sandstones. Fragments of marine molluscs and rare well-rounded extraformational clasts averaging $1-1.5 \mathrm{~cm}$ in diameter were observed randomly scattered throughout the facies association. Generally, it is churned to such an extent $(B I=4-6)$ that primary sedimentary structures are not well defined and limited to occasional millimetre-scale planar and low-angle laminations in the less bioturbated horizons. Discrete intervals of softsediment-deformed sandstone beds, as much as $1.5 \mathrm{~m}$ thick and characterized by recumbent folds, occur intermittently along the outcrop belt, more often at the top of this facies association and close to its vertical transition with the overlying FA-2 (Fig. 4B). Separation of the folded deposits from 
enclosing undeformed beds is by a generally flat lying, slightly erosive basal surface and a concordant planar upper contact.

The identified trace fauna is largely dominated by straight to gently curved, mostly horizontal to subhorizontal, 10-15 mm in diameter, unbranched cylindrical burrows of large Macaronichnus isp. (Fig. 4C), but also comprises specimens of Rosselia socialis (Fig. 4D). Other trace fossils are very rare and include some isolated burrows of Skolithos linearis. The burrows are slightly more resistant to weathering than the surrounding matrix, and commonly weather out of the rock.

Interpretation. The overall paucity of physical sedimentary structures, restricted to the presence of rare horizontal lamination, the absence of storm-induced sedimentary structures, such as hummocky and swaley cross-stratification, and the almost complete biogenic homogenisation of the sediment, indicate that low-energy conditions prevailed during deposition of this facies association. Unstable sea-floor conditions are indicated by the occurrence of soft-sediment structures. Triggering mechanisms are unknown, but this instability may have been imparted by seismic disturbances or, less likely, by infrequent large magnitude storms.

The trace fossil Macaronichnus segregatis (Clifton and Thompson, 1978) is a deep intrastratal trail representing the work of deposit-feeding polychaetes and commonly occurs as a pervasive structure in shallow-marine sandstone deposits (Seike et al., 2011). The larger (5-15 $\mathrm{mm}$ in diameter) Macaronichnus burrows described here are very similar to those of standard $M$. segregatis in all but size. Previous studies have reported large burrows of Macaronichnus in nearshore deposits at several localities including Pliocene deposits of Spain (Aguirre et al., 2010), and Pleistocene deposits in Japan (Nara, 2002). Rosselia records opportunistic colonization by burrow-dwelling, superficial detritus-feeding polychaetes, probably during low-energy intervals. Trace-fossil assemblages dominated by robust $R$. socialis and M. segregatis, comparable to that described herein, have been documented in shoreface sandstone by Howard and Frey (1984), Walker and Bergman (1993) and Aguirre et al. (2010). The resulting trace-fossil suite, overwhelmingly dominated by deposit-feeding structures, corresponds to a proximal expression of the Cruziana Ichnofacies (Pemberton et al., 2012 and references therein). The above lines of evidence indicate that deposition occurred above fair-weather wave base, in a low-energy lower-shoreface setting with infrequent storm influence similar to that described by Raychaudhuri et al. (1992).

\subsection{Facies Association 4 (FA-4): gravelly lag and cross-laminated sandstone (transgressive upper shoreface)}


Description. Sediments of this facies association form a 5-8 m-thick, landward-stepping (southwestward) sand bodies that show an onlapping geometry on top of underlying sediments, resulting in a southwestward stratigraphic rise of the contacts, and grade upward into the FA-3 lower-shoreface deposits. In the lower part, they consist of a mixture of well-rounded pebbles, granules and coarse-grained sandstones whose thickness, ranging from one clast to about $0.2 \mathrm{~m}$ (Fig. 4E), usually vary both downdip and laterally. These deposits rest directly on a sharp erosion surface showing little, if any, local relief. When overlying the mud-rich sediments of the FA-1 facies association, this surface is demarcated by Thalassinoides burrows that penetrate to depths of as much as $0.5 \mathrm{~m}$ into the underlying beds. Burrows are about $2-3 \mathrm{~cm}$ in diameter, are unlined, and are usually filled with coarse sands and granules infiltrated from the overlying unit, suggesting development of a Glossifungites firmground surface.

Up-section, these gravelly deposits pass into medium- to coarse-grained sandstones characterized by high-angle, multidirectional, small- and medium-scale trough and planar cross-bedded sets (typically 15-45 cm thick), with rare scattered pebbles and pebble stringers (Fig. 4E). Mud rip-ups and lithic clasts are present along set boundaries and on foresets. Shell debris is present in some beds as a minor component. Straight crested wave ripples, often symmetrical, on top of individual cross-bedded sets, are locally draped by infrequent, very thin and discontinuous mud drapes. Crests of the wave ripples have NW-SE orientations, implying an orientation roughly parallel to the inferred trend of the palaeoshoreline. Palaeocurrent directions recorded by the high-angle trough and planar cross-stratification show a wide scatter, although shoreline-parallel, southeastward and northwestward orientations tend to predominate. Trace fossils are rare or absent $(\mathrm{BI}=0-2)$.

Interpretation. Compared to the immediately overlying FA-3 lower-shoreface deposits described above, a more proximal marine depositional setting can be inferred for the cross-laminated sandstones from the coarser sediment calibre, the general lack of visible bioturbation, and the greater variety of wave- and current-generated sedimentary structures. Planar and trough crossstratification denotes migration of two- and three-dimensional bedforms. The abundance of shoreline-parallel and oblique palaeocurrents implies that strong longshore currents subjected to periodic changes in direction and intensity transported large volumes of sand (e.g. Clifton et al., 1971; Hart and Plint, 1989; Walker and Plint, 1992; Frébourg et al., 2012). Wave action is indicated by the presence of symmetrical and near-symmetrical ripples, the latter interpreted as produced by combined flows. Mud drapes above ripples are probably connected to buoyantly supported hypopycnal plumes of river-derived fine sediments during fair-weather conditions. All these features are indicative of sediment transport and deposition in a wave influenced upper-shoreface 
environment subjected, in the build up and surf zones, to multidirectional current flows (e.g. Burgeois and Leithold, 1984; Clifton and Dingler, 1984; Church and Middleton, 2003). The occurrence of a Glossifungites Ichnofacies supports the erosional nature of the basal surface. In siliciclastic settings, indeed, this ichnofacies is commonly associated with firm clayey substrates erosionally exhumed during transgression (e.g. Pemberton and MacEachern, 1995; Ghibaudo et al., 1996; Buatois et al., 2002; Di Celma et al., 2002). Within this frame, the basal erosional surface is interpreted as a wave ravinement surface, a wave-cut scour marking the landward passage of an erosional shoreface during sea level rise (e.g. Swift, 1968; Nummedal and Swift, 1987).

Accordingly, the gravelly deposits at the base of this facies association most likely represent a wave winnowed transgressive lag, with coarse material being supplied to the shoreface by truncation of both the underlying substrate and precursor transgressive deposits landward of the ravinement surface, probably in combination with contemporaneous fluvial input (e.g. Swift et al., 1991; Abbott, 1998; Cattaneo and Steel, 2003 and references therein). This interpretation is supported by the landward onlap termination exhibited by these strata, which implies retrogradation of the shoreface and the presence of a transgressive shoreline trajectory (e.g. Helland-Hansen and Martinsen, 1996; Helland-Hansen and Hampson, 2009).

\subsection{Facies Association 5 (FA-5): cross- and plane-parallel laminated sandstone (progradational sandy beach)}

Description. This facies association forms a sharp-based sand body that is about $5.5 \mathrm{~m}$-thick in outcrop and up to $20 \mathrm{~m}$-thick in the subsurface. Its lower part is characterized by a series of shallow, cross-cutting concave-up features (swales) that are as much as $2 \mathrm{~m}$ wide and a few tens of centimetres deep and filled by gently dipping, broad concave-up laminae concordantly draping the lower bounding surface (Fig. 4F). Zones of mudstone rip-up clasts are common along the lower scoured surface and concentrations of shell fragments are present along some laminae. Up-section, this basal portion passes into amalgamated beds of plane-parallel laminated and highangle trough and planar cross-bedded sandstones in sets several tens of centimetres thick, with granules and small pebbles occurring either isolated or in rare bands no thicker than $5 \mathrm{~cm}$. Palaeocurrent measurements derived from cross-bedding indicate a dominant southeastward flow direction. Two- and three-dimensional wave ripple structures are also commonly found. Trace fossils are sparse to absent $(\mathrm{BI}=0-2)$ and mostly concentrated along intervening horizons displaying intense reworking by large Macaronichnus. Gradually overlying this middle part are well-sorted, medium-grained, plane-parallel laminated sandstones in wedge-shaped sets that dip seaward at low angles. The lamination is defined by textural variations or by concentrations of 
heavy minerals. This interval is typically devoid of all biogenic structures (BI ranging between 0 and 1), with the exception of some isolated large Macaronichnus and vertical Skolithos. Due to intense bioturbation by rootlets, the uppermost $1.5 \mathrm{~m}$ of FA-5 is usually massive, with the root traces subtending from a laterally extensive, planar top surface associated with a reddish paleosol (Fig. 4G).

Interpretation. Through analogy with outcrop studies, the sandy facies characterized by swaleyfilling concave-up laminae associated with rare hummocks is interpreted to represent swaley crossstratification (Leckie and Walker, 1982), also known as amalgamated hummocky-stratification (Leithold and Burgeois, 1984). This sedimentary structure is widely thought to be the result of a combination of powerful storm-generated unidirectional and oscillatory flows at and above the limit of the fair-weather wave base (e.g. Dott and Bourgeois, 1982; Surlyk and Noenygaard, 1986; Arnott, 1992). The presence of interbedded parallel-laminated and cross-laminated facies along with the overall paucity of bioturbation suggest that these sediments were deposited in an storm/wave influenced upper-shoreface setting subjected to wave-induced multidirectional currents (e.g. Burgeois and Leithold, 1984; Clifton and Dingler, 1984; Church and Middleton, 2003). In this setting, based on the palaeocurrent pattern, cross-bedded sandstones are interpreted to record the migration of bedforms in response to longshore currents, whereas deposition of upper flow regime plane-parallel-laminated sandstones is thought to occur during storm episodes when the maximum orbital velocities, as well as mean residual current velocities, are high (Hill et al., 2003). The monospecific assemblage of large Macaronichnus probably represents opportunistic colonization of the shifting sandy substrate by deposit feeders during fair-weather conditions (Savrda et al., 1998; MacEachern et al., 2005; MacEachern and Bann, 2008; Aguirre et al., 2010; Pemberton et al., 2012). Similarly, wave-ripple cross-laminated sandstone beds record weak reworking of the seabed during fair-weather conditions. The seaward-dipping, low-angle, plane-parallel-laminated sandstones in the uppermost part of this facies association are interpreted as foreshore deposits in which plane-parallel-lamination is formed under upper flow regime due to intense swash and backwash processes. The interpretation is supported by the occurrence of root traces and a capping paleosol, indicating a prolonged period of sub-aerial exposure and pedogenic alteration of the deposits. These sharp-based, regressive deposits indicate limited accommodation in front of the prograding shoreface and represent a relative drop in sea level. Correspondingly, a descending accretionary regressive shoreline trajectory is attributed to these deposits (e.g. Helland-Hansen and Martinsen, 1996; Helland-Hansen and Hampson, 2009). 


\subsection{Facies Association 6 (FA-6): large scale, clast-supported, inclined conglomerates}

\section{(progradational gravel beach)}

Description. This facies association is only exposed at Punta di Acquabella and consists of a progradational package of large-scale, NE-inclined clinothems that are up to $8 \mathrm{~m}$ high. Successively younger clinothems build outwards and downwards from a seaward dipping upper surface characterized by lack of topset strata and by pronounced offlap terminations of foreset strata. Downdip, foreset strata terminate by downlap onto an erosional, seaward dipping basal surface. In terms of grain size, the composition of this facies association changes significantly in a downdepositional dip direction from dominantly conglomerate in the proximal part to dominantly sandstone in the more distal part. The clasts are calcareous and cherty, indicating an Apenninic provenance.

In their proximal (updip) part, sediments of the FA-6 consist of 10-50 cm thick, seaward-dipping clinothems of well-rounded, granule to pebble conglomerates displaying a fairly good to excellent segregation of clasts of different sizes into separate beds. Conglomerates are mostly clast-supported and closely packed with sand or granule matrix, although open framework conglomerates are preserved locally. Component clasts are of spherical, equant, rod to discoidal shapes with the latter being dominant and with a pronounced seaward-dipping imbrication (Fig. 4H). When tracing the foresets downdip, they exhibit considerable variations in textural and bedding characteristics including a progressive decrease in degree of segregation and sorting of clasts and transition into larger, more spherical and sometimes rod-shaped clasts characterized by a relatively thick, poorly distinct stratification. The average dip of these foresets is $18^{\circ}$, but this decreases gradually in both updip and downdip directions to less than $10^{\circ}$ producing gently oblique clinothems.

These proximal conglomerates are underlain by, and passes downdip into, alternating decimetrescale sandstone beds and sharp-based conglomerate layers. Conglomerate layers are some decimetres to one-clast thick, usually poorly sorted and in the pebble-cobble size-range. Sandstone layers display onshore dipping planar cross-lamination and also contain symmetrical wave ripples. In sections normal to palaeoshoreline, the sandstone and the conglomerate layers form interfingering tongues rapidly wedging-out in a landward and seaward direction, respectively (Fig. 4I).

Interpretation. Massari and Parea (1988) regarded each sharp-based gravel-sand couplet of the distal portion as the record of, respectively, storm and post-storm recovery stages in the upper shoreface setting of progradational gravel beaches deposited in wave-dominated littoral environments (Bourgeois and Leithold, 1984; Hart and Plint, 1989, 1995). The same authors 
interpreted the conglomerate-prone proximal portion as wave-worked beachface conglomerates. In this setting, the beach profile exerts an important control on sorting of particles with almost planar beds of being stable in the upper beachface, whereas less well-sorted, larger and more spherical pebbles tend to roll downslope into the lower beachface (Bluck, 2011). The downstepping, shingled geometry of these gravelly clinothems describes a descending regressive trajectory of the shoreline (e.g. Helland-Hansen and Martinsen, 1996; Helland-Hansen and Hampson, 2009) and, together with their sharp basal surface, is concordant with conditions of limited accommodation in front of the prograding shoreface during relative sea-level fall.

4.7. Facies Association 7 (FA-7): calcareous marls and interbedded grey-green mudstones and very fine-grained sandstones (palustrine carbonates and back-barrier coastal lagoon)

Description. The lower part of this facies association comprises calcareous marls up to $0.5 \mathrm{~m}$ thick. At the macroscopic scale, polished slabs of the lower portion of this unit show a complex fabric of mottled, light yellowish to pale orange patches of iron and manganese concentrations and spherical to subspherical ferruginuous nodules with diameters of several millimetres to centimetres. Locally, this mottled horizon is overlain by a $0.1-0.15 \mathrm{~m}$-thick horizon characterized by stromatolitic, very irregularly laminated micrites that, in turn, is succeeded by intensively rooted, massive chalky marls featuring a distinctive molluscan fauna (Fig. 4J). The invertebrate fauna assemblage preserved in these sediments is represented by a mixture of complete freshwater snails (Valvata sp. and Bithynia sp.) and numerous whole or nearly whole moulds of one hydrophilic land snail (Cepaea sp.) (D. Esu, 2014, personal communication).

The calcareous marls are overlain by a mud-rich facies association up to $15 \mathrm{~m}$-thick of grey and grey-green massive mudstones containing coaly fragments of interpreted land plant origin and subordinate silty, very fine-grained, massive-bedded sandstones. The most characteristic features of these sediments are the mottled aspect, due to indistinct background bioturbation, the abundant root structures and presence of thin Skolithos-type vertical burrows. The fossil content is abundant and consists of mollusc remains that are found either scattered or arranged in shell beds with a denselypacked bioclastic fabric. The mollusc association is characterized by Cerastoderma glaucum, Abra segmentum, Hydrobia cf. acuta and Ventrosia ventrosa. Moreover, micropalaeontological analyses revealed a microfaunal association mainly composed of typical brackish foraminiferal and ostracod species. Particularly, the foraminiferal association is dominated by Ammonia beccarii with subordinate Cibicides sp. and Elphidium crispum. The ostracod fauna is composed almost entirely of valves of Cyprideis torosa, which is generally the dominant species, and a few scattered valves of Leptocythere sp. 
Interpretation. The calcareous marls exhibit some of the typical features (mottling, ferruginous nodules, root and stromatolite-like structures) encountered in freshwater palustrine limestones deposited in seasonal wetlands (marl prairies) in absence of significant clastic input and under semiarid to intermediate climatic conditions (e.g. Platt and Wright, 1992; Tandon and Gibling, 1997; Armenteros and Huerta, 2006; Reuter et al., 2009; Alonso-Zarza and Wright, 2010 and reference therein; Tanner, 2010). It is therefore suggested that it is the product of mixed pedogenic and phreatic processes associated with an ancient coastal wetland with the water table at or close to the surface and characterized by more or less densely vegetated areas of carbonate-producing freshwater marshes and swamps. Carbonates deposited in these settings are almost always impure, containing varying quantities of clay, and mottling is a phreatic feature documenting the remobilization of iron as a consequence of changes in the Eh of fluctuating water tables and form in seasonally saturated portions of profiles (Freytet and Plaziat, 1982; Platt, 1989). The apparently conflicting co-occurrence of terrestrial and freshwater biota can be explained by alternating conditions of exposure and inundation (Freytet and Plaziat, 1982; Freytet and Verrecchia, 2002; MacNeil and Jones, 2006; Reuter et al., 2009; Hanneman and Wideman, 2010; Suarez-Gonzalez et al., 2015).

The mollusc and microfaunal assemblages documented within the overlying mud-rich unit show remarkable similarity with those described within present day Mediterranean brackish-water coastal lagoons and estuaries or coastal lakes (e.g. Gravina et al., 1989; Koutsoubas et al., 2000; Gontikaki et al., 2003; Murray, 2006; Basset et al., 2007, Carboni et al., 2009; Nachite et al., 2010) and from numerous buried late Quaternary lagoonal successions (e.g. Primavera et al., 2011; Carboni et al., 2002, 2010; Amorosi et al., 2014). Accordingly, these palaeontological features, together with the fine grain size, suggest that the mud-rich portion of this facies association resulted from deposition in a brackish-water back-barrier lagoon that was connected intermittently to the sea by one or more ephemeral inlets. Within this setting, the thin sandstone layers intercalated in the mud prone unit are interpreted to represent washover fan deposits accumulated within the standing water of the lagoon by storm waves cutting through and overtopping the adjacent sandy barrier.

Overall, the vertical superposition of sedimentary facies documented within this marginal marine facies association indicates that its lower part was deposited in a coastal wetland where freshwater influence was dominant; seawater influence increased through time developing lagoon brackish conditions that terminated deposition of palustrine carbonates and allowed deposition of the overlying mud-rich unit in response to sea-level rise. 


\subsection{Facies Association 8 (FA-8): clast-supported conglomerates (braided fluvial channels}

deposits)

Description. This facies association occurs as three partially amalgamated, flat-topped lenticular conglomerate units that are bounded at the base by sharp surfaces with up to $8 \mathrm{~m}$ of erosional relief (Fig. 4K). Individual conglomeratic sedimentation units, up to $2 \mathrm{~m}$ thick and ranging from less than 0.5 to $2 \mathrm{~m}$ in length, are clast-supported and consist primarily of well-rounded, granule- to cobblesized clasts. The matrix commonly consists of silt and poorly sorted sand-grade particles. Outsized intraformational clasts, typically elongated and extremely angular in shape, are uncommon and mostly occur along the basal erosion surface (Fig. 4L). Bedding geometry is highly variable and ranges from tabular to broadly lenticular on a scale of metres to tens of metres, with frequent and abrupt lateral variations in thickness due to amalgamation, bed truncations, and erosional wedging out of individual beds. Massive conglomerates predominate in this lithofacies, but some either contain normal and inverse grading or large-scale cross-stratification. Palaeocurrent directions interpreted from $a(\mathrm{t}) b(\mathrm{i})$ clast imbrication indicates the main transport direction towards the NE; therefore, the main outcrop (Ripari di Giobbe) is primarily oriented along depositional strike. This facies association is characterized by a complex mosaic of erosion surfaces that define a multistorey, multi-lateral framework of lenticular conglomerates. Intersecting erosional contacts are mainly planar and concave-upwards or obscured because of the lack of well-defined bedding. In places, conglomerates are interbedded with horizontal to gently inclined, either massive or crosslaminated sandstone beds, generally lesser than $50 \mathrm{~cm}$ thick and no more than a few metres in lateral extent. Internally, the bedding is organized into one or two sets of gently inclined lateral accretion surfaces defined by interbedding between conglomerate and variably thick sandstone partings. Where exposure is fresh, it is possible to recognize a distinctive decrease in grain size obliquely upward the accretion surfaces. In a few cases, the inclined beds are seen to dip into a mud-filled channel form (Fig. 4M).

Interpretation. The gravelly facies association represents a variety of channel-fill gravel beds and bar forms. The erosional bases and lenticular shapes in bodies of this facies association is consistent with deposition in shallow incised channels of low sinuosity that were up to $3 \mathrm{~m}$ deep and a few tens of metres wide. The large-scale inclined bedsets seen in some of the conglomerates are indicative of lateral accretion and, as such, are interpreted to define gravel braid bars. Overall, the coarse grain-size of the channel fill sediments, the predominance of sediments recording migration of gravelly longitudinal bars and the multi-storey character of the deposit, indicate high-energy discharge and prevailing bed-load transport within a shifting network of shallow, unstable, low 
sinuosity braided channels that were active simultaneously within a channel belt (e.g. Smith, 1974; Hein and Walker, 1977; Miall, 1996; Siegenthaler and Huggenberger, 1993; Browne and Naish, 2003).

\subsection{Facies Association 9 (FA-9): organic-rich mudstones and horizontal-bedded sandstones} (floodplain deposits)

Description. This facies association consists of laterally discontinuous packages up to $5 \mathrm{~m}$ thick of grey, root penetrated, planar laminated to massive mudstones and sporadic, very thin siltstone beds rich in tree branches, small trunks and pulmonate gastropods (Fig. 4N). Associated with these mudstones (FA-9a) are packages of very fine- to fine-grained sandstones typically arranged in normally graded, 5-30 cm thick tabular beds with erosive and transitional bases (FA-9b). Sedimentary structures are not well exhibited but horizontal or low-angle cross-lamination and current ripple lamination are preserved in some beds. The lower bounding surface of the sandstone bedset is conformable to erosional, whereas its upper bounding surface is eroded by younger fluvial channel conglomerates.

Interpretation. Strata of this facies association represent a variety of subenvironments in a floodplain setting. The fine-grained nature and the presence of well-preserved roots, tree trunks, and pulmonate gastropods show that the grey mudstones and siltstones represent overbank deposits within an intensely vegetated inter-channel area (Kraus, 1987). As attested by their geometry, erosive base, normal grading and sedimentary structures, the sandstone beds were deposited by expanding, unconfined, turbulent flows. In this scenario, they would represent crevasse splay deposits laid down when the bank of a nearby fluvial channel was breached and sediment was dispersed over the adjacent floodplain (Smith et al., 1989). The thickness, grain size and lateral continuity of crevasse-splay beds are interpreted to reflect relative proximity to nearby fluvial channels.

\section{Discussion}

\subsection{Sequence stratigraphic organization}

The sequence stratigraphic framework constructed for the Qm2 Unit hinges upon careful interpretation of previously unrecorded key stratigraphic surfaces recognizable in both outcrop sections and cores and the description and interpretation of vertical facies trends and lateral facies relationships within the intervening stratal units. Based on the documentation of distinctive facies stacking patterns, vertical and lateral distribution of interpreted facies associations, facies 
dislocations across major surfaces, and presence of different types of stratal terminations, the studied interval has been subdivided into three unconformity-bounded depositional sequences and their component systems tracts. Sequence-bounding unconformities, identified from a variety of evidence, were named with the addition of a numeric subscript. To facilitate description, the intervening sequences were named for their lower bounding surface and component systems tracts have a subscript referring to the sequence. Because this study examines the distal exposures of the Qm2 Unit, the top-down nomenclature allows potentially older sequences to be identified and consecutively numbered in the extensive exposures of the Qm2 Unit to the west of the study area. Within Qm2, individual sequences were formed landward of the lowstand shoreline and can be interpreted in terms of transgressive and falling stage systems tracts, documenting a single relative sea-level fluctuation in the form of a transgressive-regressive (T-R) cycle. The roughly time equivalent outer-shelf to upper-slope lowstand wedges are situated far seaward, many kilometres east of the modern Adriatic coast and were observed in high-resolution seismic reflection profiles of the subsurface Adriatic Sea (Scrocca, 2006; Dalla Valle et al., 2013; Tinterri and Lipparini, 2013). Due to their proximal palaeogeographic position, the valley fills described herein are assigned to the transgressive systems tract. Highstand systems tract deposits have not been positively identified within the three sequences. If present, they are probably very thin, this reflecting the short duration of time spent in the highstand condition by the sea level during mid-Pleistocene glacio-eustatic oscillations.

\subsubsection{Boundaries and systems tracts of sequence $Q m 2_{3}$}

Judging from integrated outcrop and subsurface data, sequence $\mathrm{Qm} 2{ }_{3}$ only occurs at the southern end of the study area (Fig. 5). It exhibits a prominent thinning in a seaward direction and is completely absent north of the Ortona arbour. In terms of facies variations, stratigraphic patterns and geometrical relationships, the $\mathrm{Qm} 2{ }_{3}$ sequence is very similar to the Falher $\mathrm{C}$ sub-member of the Spirit River Formation described by Caddel and Moslow (2004) in the Lower Cretaceous of the northeastern British Columbia.

\subsubsection{Transgressive systems tract $\left(\mathrm{TST}_{3}\right)$}

Description. At Punta di Acquabella (section 26), FA-4 upper-shoreface conglomerates and sandstones rest directly upon underlying FA-1 shelf mudstones of the Qm1 Unit and are gradually overlain by FA-3 lower-shoreface sandstones. The lower contact of the upper-shoreface sediments is expressed by a sharp, seaward-facing erosional surface that in the subsurface can be traced with confidence between cores 7A and 9A. Between section 26 and core 7A this surface is clearly 
dipping seaward and shows a $22 \mathrm{~m}$ rise over a downdip distance of $c a .780 \mathrm{~m}$, which implies a seaward-dipping gradient of about 1:35.

Interpretation. Given the overall deepening-upward trend recorded by the vertical juxtaposition of facies associations, these sandstones are interpreted as the product of a backstepping shoreface system developed during relative sea-level rise and transgression ( $\mathrm{TST}_{3}$ ), pushing the shoreline south of core 7A. As a result, the underlying seaward-dipping erosion surface is interpreted to represent the wave ravinement surface superimposed upon, and coincident with, the antecedent subaerial unconformity $\left(\mathrm{SU}_{3} / \mathrm{wRS}_{3}\right)$ and across which all traces of subaerial exposure have been removed by erosion during shoreface retreat.

\subsubsection{Falling stage systems tract $\left(F S S T_{3}\right)$}

Description. At Punta di Acquabella (section 26), the prograding FA-6 beachface-shoreface conglomerates erosionally overlie the lower-shoreface sandstones of $\mathrm{TST}_{3}$, documenting an unconformable basinward shift in facies. Between cores 7A and 2A, the descending shoreline trajectory indicates a fall of relative sea level of $c a .40 \mathrm{~m}$ associated with a basinward shoreline translation of $c a .1000 \mathrm{~m}$, which implies a seaward-dipping gradient of about 1:25. The most distal occurrence of FA-6 beachface-shoreface conglomerates occurs at core $2 \mathrm{~A}$, where they are seen to rest sharply onto FA-1 offshore mudstones. Beyond core $2 \mathrm{~A}$, this facies association gradually thins and pinches out in the downdip direction.

Interpretation. The seaward descending trajectory of clinothems, together with the presence of an abrupt basinward shift in facies at their sharp basal surface and the lack of topset strata, indicates that this sediment wedge reflects progradation during forced regression (e.g. Plint and Nummedal, 2000 and references therein; Helland-Hansen and Hampson, 2009). As such, it is interpreted as the falling stage systems tract of sequence $\mathrm{Qm}_{2}{ }_{3}\left(\mathrm{FSST}_{3}\right)$ and the erosional contact at its base as the regressive surface of marine erosion $\left(\mathrm{RSME}_{3}\right)$, a diachronous surface produced by shoreface incision as a consequence of lowered wave base (Plint, 1988; Plint and Nummedal, 2000). The upper bounding surface of the $\mathrm{FSST}_{3}$ stratal unit is interpreted as a sequence boundary and surface of subaerial exposure marking the base of the $\mathrm{Qm} 22$ sequence $\left(\mathrm{SU}_{2}\right)$. Due to the pronounced descending trajectory of $\mathrm{FSST}_{3}$ and the erosion at its downward-cutting basal surface, the thickness of the underlying $\mathrm{TST}_{3}$ decreases dramatically northwards (palaeo-seaward) to a point, between core $3 \mathrm{~A}$ and core $2 \mathrm{~A}$, where it is completely removed. Beyond the most basinward extent of $\mathrm{TST}_{3}$, 
$\mathrm{RSME}_{3}$ merges with $\mathrm{SU}_{3} / w \mathrm{RS}_{3}$ to form a complex polygenetic surface $\left(\mathrm{SU}_{3} / \mathrm{RSME}_{3}\right)$ through which the beachface-shoreface strata of FSST $_{3}$ rest sharply on underlying Qm1 offshore mudstones.

\subsubsection{Boundaries and systems tracts of sequence $Q m 2_{2}$}

\subsubsection{Transgressive systems tract $\left(\mathrm{TST}_{2}\right)$}

Description. In distal sections, such as in the Ripari di Giobbe area, the lower part of this sequence consists of an erosively based, upward-deepening facies succession including FA-4 upper-shoreface conglomerates and sandstones that rest on a Glossifungites-demarcated erosional surface and pass gradationally upwards into FA-2 offshore-transition sandy mudstones. This upward-deepening trend of sedimentary facies culminates in a sharp erosion surface. Subsurface correlations (Figs 5,6) and outcrop observations (Fig. 7) indicate that sediments of this nearshore to inner-shelf package onlap onto an erosional surface that cuts through bedding in the underlying strata, and climbs stratigraphically in a paleolandward (southwest) direction. Between core 7A and measured section 20 , the transgressive shoreline trajectory indicates a rise of $45 \mathrm{~m}$ associated with a landward shoreline translation of $c a .3 \mathrm{~km}$, denoting an average basinward gradient of the surface of $c a .1: 66$. In most proximal areas (between cores 4A and 7A), sharply underlying this surface are FA-7 paralic sediments that, in turn, overlie FA-6 conglomerates of FSST $_{3}$.

Interpretation. The deepening-upward vertical progression of sedimentary facies, including FA-7 palustrine and lagoonal deposits (in most proximal areas) sharply overlain by FA-4 upper-shoreface sandstones grading upward into FA-2 offshore-transition sandy mudstones, argue strongly for a transgressive origin for the described succession. This sediment package is interpreted to reflect the landward migration during transgression of a coupled back-barrier/shoreface system and defines the transgressive systems tract of the $\mathrm{Qm}_{2}$ sequence $\left(\mathrm{TST}_{2}\right.$ ). Between Ripari di Giobbe to the north and Punta di Acquabella to the south, the low-angle transgressive shoreline trajectory resulted into a non-accretionary transgression, with the base of TST $_{2}$ marked by a sharp, transgressively-modified sequence boundary $\left(\mathrm{SU}_{2} / \mathrm{wRS}_{2}\right)$. There, strong wave scouring during the transgression has stripped off a variable thickness of underlying sediments removing all the evidence of subaerial exposure during the preceding relative fall and lowstand of sea level and forming a prominent, pebblemantled wave ravinement surface (Fig. 4E) (Nummedal and Swift, 1987; Saito, 1994; Cattaneo and Steel, 2003). Because Qm23 deposits have not been identified in the northern portion of the study area (San Marco and Ripari di Giobbe sites), in that area $\mathrm{SU}_{2} / \mathrm{wRS}_{2}$ is inferred to converge with the antecedent $\mathrm{SU}_{3}$ resulting in a composite amalgamation surface. At the southern (paleo-landward) limit of the study area, between cores $4 \mathrm{~A}$ and $7 \mathrm{~A}$, the presence of a package of back-barrier paralic 
sediments (FA-7) enveloped by $\mathrm{SU}_{2}$ and $\mathrm{wRS}_{2}$ suggests that the transgressive shoreline trajectory became significantly more accretional (ascending) in a landward direction.

Between cores $6 \mathrm{~A}$ and $5 \mathrm{~A}$, the difficulty to pinpoint the physical surface necessary to discriminate late transgressive deposits from those emplaced during the early phase of normal regression (highstand) prevents an unambiguous attribution of sediments.

\subsubsection{Falling stage systems tract $\left(F_{S S T}\right)$}

Description. Basinward of core 4A, sharply overlying the $\mathrm{TST}_{2}$ deposits, is a shallowing-upward facies succession including upper-shoreface and foreshore sandstones (FA-5) culminating with a phase of subaerial exposure recorded by the development of a rooted soil horizon (Figs. 8A, 4G). The lower boundary is a conspicuous lithological contact (Fig. 8B) that is typically defined by the sand-rich FA-5 shoreface/foreshore deposits sharply overlying truncated units of FA-2 offshore transition deposits (Fig. 8B). This surface records abrupt increase in depositional energy and shallowing of water depth, implying erosion associated with a significant basinward shift of facies. Between core 5A and measured section 3, it records a northeastward movement of the shoreline of at least $2.6 \mathrm{~km}$ and a fall of relative sea level of about $45 \mathrm{~m}$, implying an average basinward gradient of $c a$. 1:58.

Interpretation. The overall shoaling-upward trend of component sedimentary facies, which culminates with a surface of subaerial exposure, and the abrupt basinward facies shift recorded at its basal surface are compelling evidence that this sandstone package represents shoreface and foreshore growth associated with a prograding beach during relative sea-level fall. Accordingly, the sharp-based shoreface/foreshore sandstones of FA-5 and the erosion surface beneath them are interpreted to represent the falling-stage systems tract $\left(\mathrm{FSST}_{2}\right)$ and the wave-scoured regressive surface of marine erosion $\left(\mathrm{RSME}_{2}\right)$, respectively (e.g. Plint and Nummedal, 2000 and references therein; Helland-Hansen and Hampson, 2009). The overlying rooted paleosol defines the upper sequence boundary $\left(\mathrm{SU}_{1}\right)$ and reflects a prolonged period of subaerial exposure and pedogenic alteration prior to deposition of Qm2 $2_{1}$

\subsubsection{Boundaries and systems tracts of sequence Qm2}

A significant change in the character of the depositional systems is marked by the unconformity at the base of this sequence, above which their dominant character varies from fluvial-dominated to lagoon-dominated, with no apparent marine influence. 


\subsubsection{Transgressive systems tract $\left(\mathrm{TST}_{1}\right)$}

Description. At Ripari Di Giobbe, in the northern part of the study area, a $1.3 \mathrm{~km}$-wide incision surface with up to $20 \mathrm{~m}$ of erosional relief deeply cuts into shoreface and inner-shelf sediments of the underlying Qm2 2 sequence and, at the deepest point of incision (Punta Ferruccio), at least $1 \mathrm{~m}$ into the subjacent Qm1 offshore strata (Fig. 4K and Fig. 9). Outside of the incision, this surface can be traced into the subaerial exposure surface at the top of $\mathrm{FSST}_{2}$. Between core 164071 and section 22 (Fig. 6), the subaerial exposure surface is clearly dipping seaward and shows a $15 \mathrm{~m}$ drop over $1.2 \mathrm{~km}$, with an average basinward-dipping gradient of 1:80. The sedimentary fill of the incision consists predominantly of multi-story fluvial channel conglomerates (FA-8), with subordinate floodplain mudstones and sandstones (FA-9). Sharply overlying both the continental sediments and the laterally adjacent paleosol is a $15 \mathrm{~m}$-thick package of paralic deposits, consisting of stacked palustrine and lagoon sediments (FA-7).

Interpretation. The successful correlation of the basal incision surface to the well-developed interfluve paleosol at the top of $\mathrm{Qm} 22_{2}$ indicates an incised fluvial valley deeply entrenched into Qm22 shallow-marine sediments. This disconformable contact represents a dramatic basinward shift in facies from outer-shelf mudstones to alluvial deposits and indicates downcutting and incision by the fluvial system in response to relative fall in base level and decreasing accommodation. The resulting sequence boundary $\left(\mathrm{SU}_{1}\right)$ is formed by the lateral combination of the fluvial entrenchment surface in the valley and the surface of subaerial exposure on the interfluves (e.g. O'Byrne and Flint, 1996; McCarthy and Plint, 1998). Backfilling of the incised valley (IVF 1 ) with fluvial channel or overbank strata commenced late in the transgression, when accommodation creation resumed in the continental region. As relative sea-level continued to rise, the shoreline migrated back across the shelf and a retrograding barrier-lagoon system ( $\left.\mathrm{TST}_{1}\right)$ developed behind the transgressing shoreline. This resulted into the establishment over both the incised-valley fill and the weathered interfluves of a fluctuating, carbonate-rich, freshwater coastal wetland that eventually evolved into a brackish lagoon within which mud-rich sediments were deposited. Sequence Qm2 1 contains no fieldobservable evidence of fully marine conditions that eventually evolved into a brackish lagoon. Given that Qm2 1 is separated from the overlying fluvial deposits of the Qc Unit by a major regional unconformity $\left(\mathrm{SU}_{\mathrm{Qc}}\right)$, truncation of the back-barrier facies association records a subsequent lowstand period.

\subsection{Stacking pattern and internal architecture of depositional sequences}


The stacking pattern and internal architecture of depositional sequences are controlled by the interplay of sediment supply and both long- and short-term available accommodation space. In diporiented section (Fig. 10), the lower boundary of the Qm2 Unit is a composite, regional-scale unconformity resulting from the lateral amalgamation of an array of discrete erosional surfaces. These surfaces were produced by the progressive basinward translation of successive sequences and include seaward-younging subaerial unconformities, regressive surfaces of marine erosion, and ravinement surfaces. The nature of the basal unconformity, along with the stepwise change towards more nonmarine conditions following each transgression, demonstrates that individual sequences stack with an overall downdip shingling configuration, where each successive sequence is displaced further basinwards and downwards than the last. This pattern in sequence arrangement (downstepping sequence set of Jones and Milton, 1994; forced regressive sequence set of McMurray and Gawthorpe, 2000; Cantalamessa and Di Celma, 2004; and Cantalamessa et al., 2006, degradational sequence set of Neal and Abreu, 2009) is coherent with high-frequency changes in accommodation space superimposed on a long-term loss in accommodation space induced by the contemporaneous uplift of the basin margin. Cantalamessa et al. (2006) and Nalin et al. (2007) have documented a strikingly similar pattern in Middle Pleistocene composite sequences of northern Chile and southern Italy, respectively, and attributed its development to successive sealevel fluctuations of comparable amplitude acting on an uplifting landmass.

Facies architecture within the studied sequences indicates that close to the maximum ingression of the shoreline the transgressive and the falling stage systems tract compose the bulk of the Qm2 high-frequency sequences, while the highstand systems tract deposits are absent or too thin to be identified. Farther seaward, the internal arrangement of stratal units and bounding surfaces deviates significantly from that commonly predicted in more extensively studied sequences that developed in subsiding, high net-accommodation settings (see Plint and Nummedal, 2000 and references therein). In the studied Qm2 $2_{3}$ and $\mathrm{Qm} 22_{2}$ sequences, indeed, wave scouring in front of the advancing forced regressive shoreline was enhanced by tectonic uplift and led to the progressive truncation of the transgressive sediments and the basinward convergence of the regressive surface of marine erosion and the underlying sequence boundary. As a result, transgressive deposits thin markedly in the basinward direction and sequences tend to be gradually skewed towards the forced regressive systems tract. Beyond the point of convergence, the transgressive sediments were completely removed together with part of the underlying deposits, the regressive surface of marine erosion was superposed on, and coincident with, the sequence boundary, and the falling-stage systems tract deposits represent the entire depositional sequence. 


\subsection{Significance to hydrocarbon exploration}

Development of an accurate sequence stratigraphic characterization of clastic shelf reservoirs, including the stratal geometry and vertical and lateral distribution of coarse-grained and muddy deposits as well as framework of key stratigraphic surfaces and facies contacts, is critical to better predict the spatial distribution of reservoir properties and understand the potential reservoir compartmentalization (Zecchin and Catuneanu, 2015). The combined outcrop and subsurface dataset used in this study permits the development of a realistic stratigraphic-sedimentologic reservoir model for high-frequency glacio-eustatic sequences developed in actively uplifting coastal settings and provides a predictable distribution of sandstone and conglomerate reservoirs and muddy confining units within them. In the studied Qm2 succession, in general, five main facies associations form reservoir-grade units of different origin and quality. These units are the nearshore sandstones (FA-3 and FA-4) and fluvial conglomerates (FA-8) of the transgressive systems tracts and the nearshore sandstones (FA-5) and conglomerates (FA-6) of the falling stage systems tracts. Conversely, due to their mud-rich character, transgressive offshore transition (FA-2), paralic (FA-7) and floodplain (FA-9) deposits represent impermeable packages serving as seals or baffles to fluid migration as well as potential source rocks.

Within sequence $\mathrm{Qm} 2_{3}$, the potential reservoirs consist of transgressive nearshore sandstones and forced regressive beach conglomerates that are underlain by shelf mudstones of the Qm1 Unit and, in the most proximal parts of the study area, partially sealed by paralic mudstones of the overlying $\mathrm{TST}_{2}$. Downdip, the sealing paralic mudstones pinch out and the reservoir units of $\mathrm{Qm} 2{ }_{3}$ become vertically connected with the transgressive reservoir sandstones of $\mathrm{Qm} 22_{2}$. Along depositional strike and dip directions, the transgressive and forced regressive reservoir sand bodies of $\mathrm{Qm} 22$ exhibit a different vertical compartmentalization potential. In a depositional strike sense, the sand-prone transgressive and forced regressive sediments are vertically separated by a variable thickness of sealing offshore transition sediments, resulting into a high vertical stratigraphic compartmentalization potential that can be only reduced by downcutting and erosion of incised fluvial valleys from the overlying Qm2 ${ }_{1}$. Across the surface of fluvial entrenchment, indeed, the transgressive infill of the incised valley is in direct contact with sediments of Qm2 2 , leading to a high degree of connectivity between potentially viable reservoir packages represented by the fluvial conglomerates and the transgressive and forced regressive reservoir sandstones of Qm2 2 . In an updip direction, stratigraphic compartmentalization potential is reduced by the progressive landward thinning of the offshore transition sediments, resulting into up-depositional dip connectivity of transgressive and forced regressive sandstones that are vertically separated in a 
depositional strike orientation. The $\mathrm{Qm} 22_{2}$ forced regressive sand body and the incised-valley fill are sealed by the impermeable lagoon mudstones of $\mathrm{Qm} 2{ }_{1}$.

\section{Conclusions}

Detailed process-based sedimentological and a high-resolution, sequence-stratigraphic interpretation of outcrop and subsurface data has led to improved understanding of the erosional and depositional processes active during the deposition of mid-Pleistocene strata exposed near the town of Ortona, eastern central Italy, and revealed the stratigraphic response to sedimentation in longterm limited-accommodation conditions. The following represent the major conclusions stemming from this study:

(1) Nine facies associations, representative of accumulation in a variety of environments ranging from fluvial, through marginal marine, to nearshore and inner-shelf settings, have been identified within the studied interval on the basis of sedimentological, ichnological, and palaeontological features.

(2) Type and distribution of sedimentary facies, combined with position and nature of a variety of previously unrecorded key stratigraphic surfaces, provided the basis for establishing a high-resolution sequence stratigraphic framework for the Qm2 Unit. The succession of facies has been resolved into three sequences, each containing a specific subset of the nine identified facies associations that is a function of the depositional systems and systems tracts preserved.

(3) On this proximal basin margin setting, no evidence support the occurrence of highstand deposits, resulting in sequences dominated by transgressive and falling stage systems tracts. Bounding unconformities were created by fluvial entrenchment and prolonged subaerial exposure during intervening periods of sea-level fall and lowstand and were commonly reworked by wave action during subsequent transgression and shoreface retreat.

(4) Deposition of the mid-Pleistocene Qm2 Unit occurred during a period of orbital control on sea-level cyclicity and it was modulated by the interaction of rapid, high-magnitude glacioeustatic changes and regional uplift. The overall stratigraphic organization of the Qm2 Unit displays a long-term degradational stacking pattern. It is characterized by a downdip shingling configuration of sequences to form a forced regressive sequence set and is suggestive of long-term low-accommodation conditions. A composite regressive surface resulting from the convergence and amalgamation of individual sequence boundaries is reconstructed at the base of the forced regressive sequence set, marking the progressive basinward translation of successive sequences. This stacking pattern records a long-term 
loss of accommodation space and was probably driven by the contemporaneous tectonic uplift of the basin margin.

(5) The architectural framework, including both stacking pattern and internal arrangement of depositional sequences, resulting from this case study has the potential to serve as an analogue for subsurface equivalents to facilitate correlation and prediction on an exploration and production scale and provides a template for understanding the distribution, connectivity, and continuity of a range of potentially viable reservoir and source/sealing packages in similar contexts.

\section{Acknowledgements}

The authors gratefully acknowledge Y. Filipponi for a preliminary interpretation of the study area during his degree thesis at the University of Camerino, the geologist A. Faraone, who provided the stratigraphy of the Ort-1 core, and J.A. MacEachern and D. Esu for their advice on some ichnological and palaeontological aspects, respectively. The authors would especially like to thank C. Di Marzio for allowing the use of photographic imagery taken in 1995. These images have proved invaluable in reconciling the stratigraphy across the exposure shown in Fig. 9B, which is now partially obscured by slumping. The detailed comments of two anonymous journal reviewers and Associate Editor M. Ito helped to sharpen the focus of the final manuscript. Funding was provided by University of Camerino research grants (FAR 2013 and 2014) held by C. Di Celma and by the affiliates of the Reservoir Characterization Project (Shell and Total).

\section{Figure Captions}

Figure 1. A) Distribution of the Plio-Pleistocene Apennine foredeep depocentres (Ghielmi et al., 2013). The square indicates the area in B. B) Synthetic geological-structural sketch of the central portion of the Peri-Adriatic Basin in the Abruzzi region.

Figure 2. Inset shows a satellite image of central Italy (Source: Google Earth) with the study area noted. Measured outcrop sections are marked by closed red circles (for clarity, the 23 sections in the northern part of the study area are marked every five from the first to the last). Closed white circles, closed yellow circles, and closed yellow squares indicate published core data from Chiocchini et al. (1994) and unpublished core data from ISPRA (2015) and from a private source, respectively. Abbreviations for names of localities mentioned in the text are as follows: LR, Lido Riccio; TM, Torre Mucchia; PF, Punta Ferruccio; RG, Ripari di Giobbe; PL, Punta Lunga; PAB, Punta di Acquabella. 
Figure 3. Depositional dip section correlation panel summarizing the geometry, lateral and vertical distribution of facies associations, and stratal bounding surfaces of the Qm2 Unit across the study area. The locations of the measured sections are shown in Figure 2. Vertical black lines mark the position of logged sections and cores.

Figure 4. Compilation of field photographs showing the main sedimentological and ichnological characters of facies associations within the Qm2 Unit. When present, a rock hammer $(30 \mathrm{~cm}$ long) and a lens cap (6.5 $\mathrm{cm}$ in diameter) are used for scale. A) Offshore transition facies association (FA-2). B) Heavily bioturbated FA-3 sandstones overlain by slumped sandstones showing a well-preserved recumbent fold with the axial surface parallel to the base and top of the deformed unit. C) Vertical section of FA-3. Large Macaronichnus is the most abundant ichnotaxon and accounts for most of the bioturbation in this facies association. The trails, which are preferentially cemented and weathers out in relief, tend to be more or less horizontal and interpenetrate but do not branch (FA-3). D) Detail of the conical upper part of a vertically oriented burrow of Rosselia socialis (FA-3), reflecting the domiciles of resilient detritus-feeding organisms. E) Close-up of FA-4 including a basal pebble lag overlain by cross-laminated sandstones. The pebble lag reflects winnowing out of finer-grained material during transgression, whereas the highly variable dip orientation of trough and planar crossstratification suggest multidirectional sediment transport. Note the extremely sharp contact on the underlying bioturbated silty clay of FA-1. F) Outcrop appearance of FA-5. The lower part is dominated by swaley cross-stratified sandstones (black arrow) that pass upward into interbedded dune-scale cross strata (white arrow) and plane-parallel laminated sandstones (yellow arrow). G) Vertical section of FA-5 showing low angle, planar-parallel-laminated foreshore sandstones overlain by a thin, reddish paleosol. Note the presence of deep root traces that penetrate this sandstone facies to depths of as much as $1.5 \mathrm{~m}$ below the paleosol. H) Nearly depositional-dip-oriented exposure of FA-6 foreshore deposits composed of welldefined, seaward inclined layers of well-sorted, imbricated, disc-shaped pebbles. I) Depositional-dip-oriented view of FA-6 showing seaward-dipping conglomerate beds that thin and pinch out to the right (i.e. down-depositional-dip) into landward migrating, mediumscale (dune) cross-stratified sandstones. J) Exposed top surface of the calcareous marls (FA-7) with internal moulds of the terrestrial pulmonate gastropod Cepaea sp. (black arrows). K) Contact between muddy floodplain deposits and channel conglomerates (white solid lines). Sharp contact at lower dotted line records FA-8 conglomerates downcutting into FA-1 mudstones and is interpreted as the $\mathrm{SU}_{3}$ sequence boundary produced during fluvial incision, Punta Ferruccio. Person for scale. L) Enlargement of the $\mathrm{SU}_{3}$ sequence boundary. Note the 
outsized intraclasts plucked up from the underlying FA-1 substrate. M) General overview showing a channel conglomerate body (FA-8) overlain by interbedded mudstones (FA-9a) interpreted as floodplain deposits. Cross beds in the channel conglomerate are defined by alternating decimetre-scale conglomerate and sandstone layers (dips vary from $5^{\circ}$ to $15^{\circ}$ ). They grew by accretion from right to left and are associated with an abandoned-channel mud plug (left-hand side of the picture).

Figure 5. South-southeast (paleo-landward) to north-northwest (paleo-basinward) oriented crosssection and stratigraphic interpretation of the Qm2 Unit in the San Donato area. Line of section shown in Figure 2. Vertical exaggeration 10x.

Figure 6. Fence diagram constructed from measured sections between Ortona and Lido di Riccio and oriented nearly parallel to depositional strike. Line of section shown in Figure 2. Vertical exaggeration $10 \times$.

Figure 7. Stratigraphy of the upper part of sequence $\mathrm{Qm} 2_{3}$ and lower part of sequence $\mathrm{Qm} 2_{2}$ at Punta di Acquabella. The FA-6 gravelly beach sediments display a descending regressive migration path, which is diagnostic of progradation under falling sea level (FSST 3 ), and are abruptly overlain by onlapping FA-4 upper-shoreface sandstones showing a transgressive trajectory. The sharp, time-transgressive, NE-dipping contact between these two facies associations is a composite erosional surface that occupies a sequence bounding position and consists of the wave ravinement surface $\left(\mathrm{wRS}_{2}\right)$ cut by wave action during erosional shoreface retreat superimposed on the antecedent subaerial unconformity $\left(\mathrm{SU}_{2} / \mathrm{wRS}_{2}\right)$.

Figure 8. Stratigraphy of sequence $\mathrm{Qm} 22$ at Torre Mucchia. A) The gradational vertical transition (solid black line) from lower-shoreface sandstones (FA-3) to bioturbated sandy mudstones (FA-2) reflects upward deepening deposition seaward of an erosional transgressive shoreface. The overlying sharp-based FA-5 sand body, which is bounded below by a wave-scoured erosion surface (dashed white line) and above by a rooted paleosol horizon (dotted white line), typically form a coarsening-upward facies succession that passes from swaley crossstratified sandstones near the base, through cross-bedded and planar-laminated sandstones in the middle portion, to wedge-shaped sets of seaward dipping, plane-parallel laminated sandstones near the top. The paleosol is interpreted to reflect a period of subaerial exposure that took place on the coastal plain after falling sea level exposed the top of FA-5 sandstones and delineates the sequence boundary between underlying sequence Qm2 2 and overlying sequence Qm2 1 . B) Detail of the sharp planar surface cutting across offshore transition bioturbated sandy mudstones (FA-2) and overlain by shoreface to foreshore sandstones (FA5). This is interpreted as a regressive surface of marine erosion $\left(\mathrm{RSME}_{2}\right)$ cut by wave scour 
during relative sea-level fall and marks an abrupt basinward dislocation of facies, from below fair-weather wave base to well above it, in response to decreasing accommodation.

Figure 9. Photos highlighting the basal fluvial erosion surface and the stratigraphic architecture of its filling spectacularly exposed at Ripari di Giobbe. A) Panoramic view of the stratigraphy exposed at Punta Lunga. Yellow lines indicate position of measures sections. B) Photomosaic of the section illustrating the surface at the base of $\mathrm{Qm} 2{ }_{1}$ incising into older upper shoreface sandstones (FA-4) at the left-hand side of the picture and down into offshore mudstones (FA1) at its right-hand side. As such, it reflects a significant basinward shift of facies and is interpreted as a sequence boundary $\left(\mathrm{SU}_{1}\right)$. Encircled person for scale. C) Close-up of the boxed area shown in B. The fluvial sediments at the base of Qm2 $2_{1}$ consist of channel-fill bodies that are stacked laterally and vertically into larger, multistory complexes. The white dotted line underscores the fluvial erosional surface at the base of Qm2 ${ }_{1}$. This surface is very irregular and characterized by erosional scours with over $1.5 \mathrm{~m}$ of relief produced by incised fluvial channels.

Figure 10. Generalised depositional dip-oriented cross section (no scale implied) illustrating a conceptual model for the stratigraphic architecture of Qm2 Unit within the study area (shaded rectangle). The overall progradation of the Qm2 Unit occurred through forced regressions and intervening landward shifts of shoreline controlled by glacio-eustatic, high-frequency oscillations superimposed on a tectonically driven long-term sea-level fall. Aver the longterm, deposition took place in a low-accommodation setting and sequences are stacked in an downstepping configuration where each successively younger sequence occurs slightly basinward and downward of older, subjacent sequences to form a tectonically enhanced, falling-stage sequence set. The surface at its base is a complex unconformity that develops diachronously basinward as a result of the downdip convergence and amalgamation of successive sequence boundaries.

\section{References}

Abbott, S.T., 1998. Transgressive systems tract and onlap shellbeds from Mid Pleistocene sequences, Wanganui Basin, New Zealand. Journal of Sedimentary Research 68, 253-268.

Agostini, S., Bertini, A., Caramiello, S., De Flavis, A.G., Mazza, P., Rossi, M.A., Satolli, S., 2007. A new mammalian bone bed from the lower Middle Pleistocene of Ortona (Chieti, Abruzzo, central Italy). In: Coccioni, R., Marsili, A. (Eds.), Proceedings of the Giornate di Paleontologia 2005, vol. 12. Grzybowski Foundation, pp. 1-5. 
Aguirre, J., de Gibert, J.M., Puga-Bernabéu, A., 2010. Proximal-distal ichnofabric changes in a siliciclastic shelf, Early Pliocene, Guadalquivir Basin, southwest Spain. Palaeogeography Palaeoclimatology Palaeoecology 291, 328-337.

Allen, J.P. Fielding, C.R., 2007. Sequence architecture within a low-accommodation setting: An example from the Permian of the Galilee and Bowen basins, Queensland, Australia. American Association of Petroleum Geologists Bulletin 91, 1503-1539.

Alonso-Zarza, A.M., Wright, V.P., 2010. Palustrine carbonates. In: Carbonates in Continental Settings: Geochemistry, Diagenesis and Applications. In: Alonso-Zarza, A.M., Tanner L.H. (Eds.), Developments in Sedimentology 62, 103-132. Elsevier, Amsterdam.

Amorosi, A., Bracone, V., Di Donato, V., Rosskopf, C.M., Aucelli, P.P.C., 2009. The PlioPleistocene succession between Trigno and Fortore rivers (Molise and Apulia Apennines): stratigraphy and facies characteristics. GeoActa 8, 1-12.

Amorosi, A., Caporale, L., Cibin, U., Colalongo, M.L., Pasini, G., Ricci Lucchi, F., Severi, P., Vaiani, S., 1998. The Pleistocene littoral deposits (Imola Sands) of the Northern Apennines foothills. Giornale di Geologia 60, 83-118.

Amorosi, A., Rossi, V., Scarponi, D., Vaiani, S.C., Ghosh, A., 2014. Biosedimentary record of postglacial coastal dynamics: high-resolution sequence stratigraphy from the northern Tuscan coast (Italy). BOREAS 43, 939-954.

Antia, J., Fielding, C.F., 2011. Sequence stratigraphy of a condensed low-accommodation succession: Lower Upper Cretaceous Dakota Sandstone, Henry Mountains, southeastern Utah. American Association of Petroleum Geologists 93, 413-447

Antia, J., Fielding, C.R., Joeckel, R.M., 2011. Multiple cycles of wave-dominated estuarine deposits in low-accommodation settings, Cretaceous J sandstone, northwestern Nebraska. American Association of Petroleum Geologists Bulletin 95, 1227-1256.

Argnani, A., Ricci Lucchi, F., 2001. Tertiary siliciclastic turbidite systems of the northern Apennines. In: Martini, I.P., Vai, G.B. (Eds.), Anatomy of an Orogen: the Apennines and adjacent Mediterranean Basins, Kluwer Academic Publishers, pp. 327-350.

Armenteros, I., Huerta, P., 2006. The role of clastic sediment influx in the formation of calcrete and palustrine facies: A response to paleographic and climatic conditions in the southeastern Tertiary Duero basin (northern Spain). In: Alonso-Zarza, A.M., Tanner L.H. (Eds), Paleoenvironmental Record and Application of Calcretes and Palustrine Carbonates. Geological Society of America Special Papers 416, 119-132.

Arnott, R.W.C., 1992. Ripple cross-stratification in swaley cross-stratified sandstones of the Chungo Member, Mount Yamnuska, Alberta. Canadian Journal of Earth Sciences 29, 1802-1805. 
Arnott, R.W.C., Zaitlin, B.A., Potocki, D.J., 2002. Stratigraphic response to sedimentation in a netaccommodation-limited setting, Lower Cretaceous Basal Quartz, south-central Alberta. Bulletin of Canadian Petroleum Geology 50, 92-104.

Artoni, A., 2013. The Pliocene-Pleistocene stratigraphic and tectonic evolution of the Central sector of the Western Periadriatic Basin of Italy. Marine and Petroleum Geology 42, 82-106.

Basset, A., Galuppo, N., Sabetta, L., 2007. Environmental heterogeneity and benthic macroinvertebrate guilds in Italian lagoons. Transitional Waters Bulletin 1, 48-63.

Benvenuti, M., Bertini, A., Conti, C., Dominici, S., 2007. Integrated analyses of litho- and biofacies in a Pliocene cyclothemic, alluvial to shallow marine succession (Tuscany, Italy). Geobios 40, $143-158$.

Bernasconi, M.P, Robba, E., 1993. Molluscan palaeoecology and sedimentological features: an integrated approach from the Miocene Meduna section, northern Italy. Palaeogeography, Palaeoclimatology, Palaeoecology 100, 267-290

Bigi, S., Conti, A., Casero, P., Ruggiero, L., Recanati, R., Lipparini, L., 2013. Geological model of the central Periadriatic basin (Apennines, Italy). Marine and Petroleum Geology 42, 107-121.

Bluck, B.J., 2011. Structure of gravel beaches and their relationship to tidal range. Sedimentology 58, 994-1006.

Bourgeois, J., Leithold, E.L., 1984. Wave-worked conglomerates - Depositional processes and criteria for recognition. In: Koster, E.H., Steel, R.J. (Eds.), Sedimentology of Gravels and Conglomerates. Canadian Society of Petroleum Geologists Memoirs 10, 331-343.

Bracone, V., Amorosi, A., Aucelli, P.P.C., Ciampo, G., Di Donato, V., Rosskopf, C.M., 2012b. Palaeoenvironmental evolution of the Plio-Pleistocene Molise Periadriatic Basin (Southern Apennines, Italy): insight from Montesecco Clays. Italian Journal of Geosciences 131, 272-285.

Bracone, V., Amorosi, A., Aucelli, P.P.C., Rosskopf, C.M., Scarciglia, F., Di Donato, V., Esposito, P., 2012a. The Pleistocene tectono-sedimentary evolution of the Apenninic foreland basin between Trigno and Fortore rivers (Southern Italy) through a sequence-stratigraphic perspective. Basin Research 24, 213-233.

Browne, G.H., Naish T.R., 2003. Facies development and sequence architecture of a late Quaternary fluvial-marine transition, Canterbury Plains and shelf, New Zealand: implications for forced regressive deposits. Sedimentary Geology 158, 57-86.

Caddel, E.M., Moslow, T.F., 2004. Outcrop sedimentology and stratal architecture of the Lower Albian Falher C sub-Member, Spirit River Formation, Bullmoose Mountain, northeastern British Columbia. Bulletin of Canadian Petroleum Geology 52, 4-22. 
Cantalamessa, G., Centamore, E., Colalongo, M.L., Micarelli, A., Nanni, T., Pasini, G., Potetti, M. and Ricci Lucchi, F., with the collaboration of Cristallini, C., Di Lorito, L., 1986. Il Plio-

Pleistocene delle Marche. In: Centamore, E., Deiana, G. (Eds.), La Geologia delle Marche. Studi Geologici Camerti, Volume Speciale, pp. 61-81.

Cantalamessa, G., Di Celma, C., 2004. Sequence response to syndepositional regional uplift: insights from high-resolution sequence stratigraphy of late Early Pleistocene strata, Periadriatic Basin, central Italy. Sedimentary Geology 164, 283-309.

Cantalamessa, G., Di Celma, C., Potetti, M., Lori, P., Didaskalou, P., Albianelli, A., Napoleone, G., 2009. Climatic control on deposition of upper Pliocene deepwater gravity-driven strata in the Apennines foredeep (central Italy): correlations to the marine oxygen sea isotope record. In: Kneller, B., Martinsen, O.J., McCaffrey, B. (Eds.), External Controls on Deep Water Depositional Systems: Climate, Sea-level, and Sediment Flux. SEPM Special Publication 92, 247-259.

Cantalamessa, G., Di Celma, C., Ragaini, L., 2005. Sequence stratigraphy of the Punta Ballena Member of the Jama Formation (Early Pleistocene, Ecuador): insights from integrated sedimentologic, taphonomic and paleoecologic analysis of molluscan shell concentrations. Palaeogeography, Palaeoclimatology, Palaeoecology 216, 1-25.

Cantalamessa, G., Di Celma, C., Ragaini, L., 2006. Tectonic controls on sequence stacking pattern and along-strike architecture in the Pleistocene Mejillones Formation, northern Chile: Implications for sequence stratigraphic models. Sedimentary Geology 183, 125-144.

Cantalamessa, G., Di Celma, C., Ragaini, L., Valleri, G., Landini, W., 2007. Sedimentology and high-resolution sequence stratigraphy of the late middle to late Miocene Angostura Formation (western Borbon Basin, northwestern Ecuador). Journal of the Geological Society, London 164, $653-665$.

Carboni, M.G., Bergamin, L., Di Bella, L., Esu, D., Pisegna-Cerone, E., Antonioli, F., Verrubbi, V., 2010. Palaeoenvironmental reconstruction of late Quaternary foraminifera and molluscs from the ENEA borehole (Versilian plain, Tuscany, Italy). Quaternary Research 74, 265-276.

Carboni, M.G., Bergamin, L., Di Bella, L., Iamundo, F., Pugliese, N., 2002. Palaeoecological evidences from foraminifers and ostracods on Late Quaternary sea-level changes in the Ombrone river plain (central Tyrrhenian coast, Italy). Geobios 35 (Suppl. 1), 40-50.

Carboni, M.G., Succi, M.C., Bergamin, L., Di Bella, L., Frezza, V., Landini, B., 2009. Benthic foraminifera from two coastal lakes of southern Latium (Italy). Preliminary evaluation of environmental quality. Marine Pollution Bulletin 59, 268-280.

Cattaneo, A., Steel, R., 2003. Transgressive deposits: a review of their variability. Earth-Science Reviews 62, 187-228. 
Centamore, E., Nisio, S., 2003. Effects of uplift and tilting in the Central-northern Apennines (Italy). Quaternary International 101-102, 93-101.

Chiocchini, U., Giorelli, R., Mangora, V., Marchese, F., 1994. La galleria Moro della linea AnconaBari tra Ortona e Casalbordino. Geologia Applicata e Idrogeologia 29, 45-62.

Clifton, H.E., Dingler, J.R., 1984. Wave-formed structures and paleoenvironmental reconstruction. Marine Geology 60, 165-198.

Clifton, H.E., Hunter, R.E., Gardner, J.V., 1988. Analysis of eustatic, tectonic and sedimentologic influences on transgressive and regressive cycles in the Upper Cenozoic Merced Formation, San Francisco, California. In: Kleinspehn, K.L., Paola, C. (Eds.), New Perspectives in Basin Analysis pp. 109-128. Springer-Verlag, New York.

Clifton, H.E., Thompson, J.K., 1978. Macaronichnus segregatis: a feeding structure of shallow marine polychaetes. Journal of Sedimentary Petrology 48, 1293-1302.

Church, M.J., Middleton, G.V., 2003. Encyclopedia of Sediments and Sedimentary Rocks. SpringerVerlag, New York, 821 pp.

Cyr, A.J., Granger, D.E., 2008. Dynamic equilibrium among erosion, river incision, and coastal uplift in the northern and central Apennines, Italy. Geology 36, 103-106.

D’Agostino, N., Jackson, J.A., Dramis, F., Funiciello, R., 2001. Interactions between mantle upwelling, drainage evolution and active normal faulting: an example from the central Apennines (Italy). Geophysical Journal International 147, 475-497.

Dalla Valle, G., Gamberi, F., Trincardi, F. Baglioni, L. Errera, A., Rocchini, P., 2013. Contrasting slope channel styles on a prograding mud-prone margin. Marine and Petroleum Geology 41, 7282.

Di Celma, C., 2011. Sedimentology, architecture, and depositional evolution of a coarse-grained submarine canyon fill from the Gelasian (early Pleistocene) of the Peri-Adriatic basin, Offida, central Italy. Sedimentary Geology 238, 233-253.

Di Celma, C., Brunt, R.L., Hodgson, D.M., Flint, S.S., Kavanagh, J.P., 2011. Spatial and temporal evolution of a Permian submarine slope channel-levee system, Karoo Basin, South Africa. Journal of Sedimentary Research 81, 579-599.

Di Celma, C., Cantalamessa, G., 2007. Sedimentology and high-frequency sequence stratigraphy of a forearc extensional basin: The Miocene Caleta Herradura Formation, Mejillones Peninsula, northern Chile. Sedimentary Geology 198, 29-52.

Di Celma, C., Cantalamessa, G., 2012. Off-shelf sedimentary record of recurring global sea-level changes during the Plio-Pleistocene: evidence from the cyclic fills of exhumed slope systems in central Italy. Journal of the Geological Society, London 169, 643-646. 
Di Celma, C., Cantalamessa, G., Didaskalou, P., 2013. Stratigraphic organization and predictability of mixed coarse- and fine-grained successions in an upper slope turbidite system of the PeriAdriatic basin. Sedimentology 60, 763-799.

Di Celma, C., Cantalamessa, G., Didaskalou, P., Lori, P., 2010. Sedimentology, architecture, and sequence stratigraphy of coarse-grained, submarine canyon fills from the Pleistocene (GelasianCalabrian) of the Peri-Adriatic basin, central Italy. Marine and Petroleum Geology 27, 1340-1365.

Di Celma, C., Pieruccini, P., Farabollini, P., 2015. Major controls on architecture, sequence stratigraphy and palaeosols of Middle Pleistocene continental sediments ("Qc Unit"), eastern central Italy. Quaternary Research 83, 565-581.

Di Celma, C., Ragaini, L., Cantalamessa, G., Curzio, P., 2002. Shell concentrations as tools in characterizing sedimentary dynamics at sequence-bounding unconformities: examples from the lower unit of the Canoa Formation (Late Pliocene, Ecuador). Geobios 35 (Suppl. 1), 72-85.

Di Celma, C., Ragaini, L., Cantalamessa, G., Landini, W., 2005. Basin physiography and tectonic influence on sequence architecture and stacking pattern: Pleistocene succession of the Canoa Basin (central Ecuador). Geological Society of America Bulletin 117, 1226-1241.

Di Celma, C., Teloni, R., Rustichelli, A., 2016. Evolution of the Gelasian (Pleistocene) slope turbidite systems of southern Marche (Peri-Adriatic basin, central Italy). Journal of Maps, 12, 137151.

Doglioni, C., 1991. A proposal for the kinematic modelling of W-dipping subductions-possible applications to the Tyrrhenian-Appennines system. Terra Nova 3, 423-434.

Dott, R.H., Jr., Bourgeois, J., 1982. Hummocky stratification: Significance of its variable bedding sequences. Geological Society of America Bulletin 93, 663-80.

Mudelsee, M., Stattegger, K., 1997. Exploring the structure of the mid-Pleistocene revolution with advanced methods of time-series analysis. Geologische Rundschau 86, 499-511.

Fielding, C.R., Bann, K.L., Maceachern, J.A., Tye, S.C., Jones, B.G., 2006. Cyclicity in the nearshore marine to coastal, Lower Permian, Pebbley Beach Formation, southern Sydney Basin, Australia: a record of relative sea-level fluctuations at the close of the Late Palaeozoic Gondwanan ice age. Sedimentology 53, 435-463.

Frébourg, G., Hasler, C.-A., Davaud, E., 2012. Uplifted marine terraces of the Akamas Peninsula (Cyprus): evidence of climatic conditions during the Late Quaternary highstands. Sedimentology 59, 1409-1425.

Freytet, P., Plaziat, J.-C., 1982. Continental carbonate sedimentation and pedogenesis - Late Cretaceous and Early Tertiary of Southern France. In: Purser, B.H. (Ed.), Contributions to Sedimentology, Springer-Verlag, 12, 217 pp. 
Freytet, P., Verrecchia, E.P., 2002. Lacustrine and palustrine carbonate petrography: an overview. Journal of Paleolimnology 27, 221-237.

Ghibaudo, G., Grandesso, P., Massari, F., Uchman, A., 1996. Use of trace fossils in delineating sequence stratigraphic surfaces (Tertiary Venetian Basin, northeastern Italy). Palaeogeography, Palaeoclimatology, Palaeoecology 120, 261-279.

Ghielmi, M., Minervini, M., Nini, C., Rogledi, S., Rossi, M., 2013. Late Miocene-Middle Pleistocene sequences in the Po Plain e Northern Adriatic Sea (Italy): The stratigraphic record of modification phases affecting a complex foreland basin. Marine and Petroleum Geology 42, 50-81.

Gontikaki, E., Antoniadou, C., Chintiroglou, C.C., 2003. Population structure of Cerastoderma glaucum and Abra ovata in Vouliagmeni Lagoon (Attiki). Journal of the Marine Biological Association of the UK 83, 1095-1097.

Gradstein, F.M., Ogg, J.G., Smith, A.G., Agterberg, F.P., Bleeker, W., Cooper, R.A., Davydov, V., Gibbard, P., Hinnov, L.A., House, M.R., Lourens L., Luterbacher, H.P., McArthur, J., Melchin, M.J., Robb, L.J., Shergold, J., Villeneuve, M., Wardlaw, B.R., Ali, J., Brinkhuis, H., Hilgen, F.J.,Hooker, J., Howarth, R.J., Knoll, A.H., Laskar, J., Monechi, S., Plumb, K.A., Powell, J., Raffi, I., Röhl, U., Sadler, P., Sanfilippo, A., Schmitz, B., Shackleton, N.J., Shields, G.A., Strauss, H., Van Dam, J., van Kolfschoten, T., Veizer, J., Wilson, D., 2004. A Geologic Time Scale. Cambridge University Press, 589 pp.

Gravina, M.F., Ardizzone, G.D., Scaletta, F., Chimenz, C., 1989. Descriptive analysis and classification of benthic communities in some Mediterranean coastal lagoons (Central Italy). Marine Ecology 10, 141-166.

Gunderson, K.L., Pazzaglia, F.J., Picotti, V., Anastasio, D.J., Kodama, K.P., Rittenour, T., Frankel, K.F., Ponza, A., Berti, C., Negri, A., Sabbatini, A., 2014. Unraveling tectonic and climatic controls on synorogenic stratigraphy. Geological Society of America Bulletin 126, 532-552.

Hanneman, D.L., Wideman, C.J. 2010. Continental sequence stratigraphy and continental carbonates. In: Alonso-Zarza, A.M., Tanner, L.H. (Eds.), Carbonates in Continental Settings: Geochemistry, Diagenesis and Applications. Developments in Sedimentology 62, 215-273. Elsevier, Amsterdam.

Hart, B.S., Plint, A.G., 1989. Gravelly shoreface deposits: a comparison of modern and ancient facies sequences. Sedimentology 36, 551-557.

Hart, B.S., Plint, A.G., 1995. Gravelly shoreface and beachface deposits. In: A.G. Plint (Editor), Sedimentary Facies Analysis. IAS Special Publication 22, pp. 75-99.

Hein, F.J., Walker, R.G., 1977. Bar evolution and development of stratification in the gravelly, braided, Kicking Horse River, British Columbia. Canadian Journal of Earth Science 14, 562-570. 
Helland-Hansen, W., Martinsen, O.J., 1996. Shoreline trajectories and sequences. description of variable depositional-dip scenario. Journal of Sedimentary Research 66, 670-688.

Helland-Hansen, W., Hampson, G.J., 2009. Trajectory analysis: concepts and applications. Basin Research 21, 454-483.

Hill, P.R., Meulé, S., Longuépée, H., 2003. Combined-flow processes and sedimentary structures on the shoreface of the wave-dominated Grande-Rivière-de-la-Baleine Delta. Journal of Sedimentary Research 73, 217-226.

Howard, J.D., Frey, R.W., 1984. Characteristic trace fossils in nearshore to offshore sequences, Upper Cretaceous of east-central Utah. Canadian Journal Earth Science 21, 200-219.

Hunt, D., Tucker, M.E., 1992. Stranded parasequences and the forced regressive wedge systems tract: deposition during base level fall. Sedimentary Geology 81, 1-9.

ISPRA, 2015. http://sgi.isprambiente.it/geoportal/catalog/main/home.page

Ito, M., Katsura, Y., 1992. Inferred glacio-eustatic control for high-frequency depositional sequences of the Plio-Pleistocene Kazusa Group, a forearc basin fill in Boso Peninsula, Japan. Sedimentary Geology 80, 67-75.

Kidwell, S.M., 1997. Anatomy of extremely thin marine sequences landward of a passive margine hinge zone: Neogene Calvert Cliffs succession, Maryland, U.S.A. Journal of Sedimentary Research 67, 322-340.

Kitamura, A., Kondo, Y., Sakai, H., Horii, M., 1994. Cyclic changes in lithofacies and molluscan content in the early Pleistocene Omma Formation, Central Japan related to the 41,000-year orbital obliquity. Palaeogeography, Palaeoclimatology, Palaeoecology 112, 345-361.

Koutsoubas, D., Arvanitidis, C., Dounas, C., Drummond, L., 2000. Community structure and dynamics of the Molluscan Fauna in a Mediterranean lagoon (Gialova lagoon, SW Greece). Belgian Journal of Zoology 130, 131-138.

Kraus, M.J., 1987. Integration of channel and floodplain suites: II, Vertical relations of alluvial paleosols: Journal of Sedimentary Petrology 57, 602-612.

Jones, R.W., Milton, N.J., 1994. Sequence development during uplift: Paleogene stratigraphy and relative sea-level history of the Outer Moray Firth, UK North Sea. Marine and Petroleum Geology $11,157-165$.

Leckie, D.A, Walker, R.G., 1982. Storm- and tide-dominated shorelines in Late Cretaceous Moosebar-Lower Gates interval - outcrop equivalents of deep basin gas trap in western Canada. American Association of Petroleum Geologists Bulletin 66, 138-157. 
Leithold, E.L., Bourgeois, J., 1984. Characteristics of coarse-grained sequences deposited in nearshore, wave-dominated environments-examples from the Miocene of south-west Oregon. Sedimentology 31, 749-775.

Longhitano, S., 2008. Sedimentary facies and sequence stratigraphy of coarse-grained Gilbert-type deltas within the Pliocene thrust-top Potenza Basin (Southern Apennines, Italy). Sedimentary Geology 210, 87-110.

MacEachern, J.A., Bann, K.L., Bhattacharya, J.P., and Howell, C.D., 2005. Ichnology of deltas: organism responses to the dynamic interplay of rivers, waves, storms and tides. In: Bhattacharya, J.P., Giosan, L. (Eds.), River Deltas: Concepts, Models and Examples, SEPM Special Publication 83, p. 49-85.

MacEachern, J.A., Bann, K.L., 2008. The role of ichnology in refining shallow marine facies models. In: Hampson, G., Steel, R., Burgess, P., Dalrymple, R. (Eds.), Recent Advances in Models of Siliciclastic Shallow-Marine Stratigraphy, SEPM Special Publication 90, p. 73-116.

MacEachern, J.A., Pemberton, S.G., Bann, K.L., Gingras, M.K., 2007. Departures from archetypal ichnofacies: effective recognition of physic-chemical stresses in the rock record. In: MacEachern, J.A., Bann, K.L., Gingras, M.K., Pemberton, S.G. (Eds.), Applied Ichnology, SEPM Short Course Notes 52, p. 65-93.

MacNeil, A.J., Jones, B., 2006. Palustrine deposits on a Late Devonian coastal plain—Sedimentary attributes and implications for concepts of carbonate sequence stratigraphy. Journal of Sedimentary Research 76, 292-309.

Malinverno, A., Ryan, W.B.F., 1986. Extension In the Tyrrenian sea and shortening in the Apennines as result of arc migration driven by sinking of the lithosphere. Tectonics 5, 227-245.

Marasti, R., 1991. Bivalvi polisiringi del Pliocene, viventi nel Mediterraneo: distribuzione e osservazioni paleoecologiche. $2^{\circ}$ Parte. (Pliocene polysyringian Bivalves living in the mediterranean: Distribution and paleoecological observations. Part 2). L'Ateneo Parmense, Acta Naturalia 26, 39-63.

Massari, F., Parea, G.C., 1988. Progradational gravel beach sequences in a moderate- to high-energy, microtidal marine environment. Sedimentology 35, 881-913.

McCarthy, P.J., Plint, A.G., 1998. Recognition of interfluve sequence boundaries: Integrating paleopedology and sequence stratigraphy. Geology 26, 387-390.

McMurray, L.S., Gawthorpe, R.L., 2000. Along strike variability of forced regressive deposits: late Quaternary, northern Peloponnesos, Greece. In: Hunt, D., Gawthorpe, R.L. (Eds.), Sedimentary Responses to Forced Regression. Spec. Publ.-Geol. Soc. London, vol. 172, pp. 363- 377. 
Miall, A.D., 1996. The Geology of Fluvial Deposits: Sedimentary Facies, Basin Analysis, and Petroleum Geology. Springer-Verlag Inc., Heidelberg, 582 pp

Milli, S., 1997. Depositional setting and high-frequency sequence stratigraphy of the Middle-Upper Pleistocene to Holocene deposits of the Roman basin. Geologica Romana 33, 99-136.

Murray, J., 2006. Ecology and Applications of Benthic Foraminifera. Cambridge University Press, Cambridge. 426 pp.

Muttoni, G., Scardia, G., Kent, D.V., Morsiani, E., Tremolada, F., Cremaschi, M., Peretto, C., 2011. First dated human occupation of Italy at $\sim 0.85$ Ma during the late Early Pleistocene climate transition. Earth and Planetary Science Letters 307, 241-252.

Nachite, D., Rodriguez-Lazaro, J., Martin-Rubio, M., Pascual, A., Bekkali, R., 2010. Distribution et écologie des associations d'ostracodes récents de l'estuaire de Tahadart (Maroc Nord-Occidental). Revue de Micropaleontologie 53, 3-15.

Naish, T.R., Abbott, S.T., Alloway, B.V., Beu, A.G., Carter, R.M., Edwards, A.R., Journeaux, T.D., Kamp, P.J.J., Pillans, B.J., Saul, G.S., Woolfe, K.J., 1998. Astronomical calibration of a southern hemisphere Plio-Pleistocene reference section, Wanganui Basin, New Zealand. Quaternary Science Reviews 17, 695-710.

Nalin, R., Massari, F., Zecchin, M., 2007. Superimposed cycles of composite marine terraces: the example of Cutro terrace (Calabria, southern Italy). Journal of Sedimentary Research 77, 340-354.

Nara, M., 2002. Crowded Rosselia socialis in Pleistocene inner shelf deposits: benthic Paleoecology during rapid sea-level rise. Palaios 17, 268-276.

Neal, J., Abreu, V., 2009. Sequence stratigraphy hierarchy and the accommodation succession method. Geology 37, 779-782.

Nummedal, D., Swift, D.J.P., 1987. Transgressive stratigraphy at sequence-bounding unconformities: some principles derived from Holocene and Cretaceous examples. In: Nummedal, D., Pilkey, O.H., Howards, J.D. (Eds.), Sea-level Fluctuation and Coastal Evolution, SEPM Spec. Publ. 41, $241-260$.

O’Byrne, C.J., Flint, S.S., 1996. Interfluve sequence boundaries in the Grassy Member, Book Cliffs, Utah: criteria for recognition and implications for subsurface correlation. In: Howell, J.A., Aitken, J.F. (Eds.), High Resolution Sequence Stratigraphy: Innovations and Applications, Geol. Soc. London Spec. Publ. 104, 207-220.

Ori, G.G., Serafini, G., Visentin, C., Ricci Lucchi, F., Casnedi, R., Colalongo, M.L., Mosna, S., 1991. The Plio-Pleistocene Adriatic foredeep (Marche and Abruzzo, Italy): an integrated approach to surface and subsurface geology. Third Conference of European Association of Petroleum Geology, Adriatic Foredeep Field Trip Guidebook, Florence, Italy. Milano, Agip S.p.A., pp. 85. 
Pedersen, P.K., Schroder-Adams, Nielsen, O,. 2002. High resolution sequence stratigraphic architecture of a transgressive coastal succession: Albian Bow Island Formation, southwestern Alberta. Bulletin of Canadian Petroleum Geology 50, 441-477.

Pemberton, S.G., MacEachern, J.A. 1995. The sequence stratigraphic significance of trace fossils in examples from the Cretaceous of Alberta. In: Van Wagoner, J.A., and Bertram, G.T. (Eds.), Sequence Stratigraphy of Foreland Basin Deposits - Outcrop and Subsurface Examples from the Cretaceous of North America. American Association of Petroleum Geologists Memoir, 64, 429475.

Pemberton, S.G., MacEachern, J.A., Dashtgard, S.E., Bann, K.L., Gingras, M.K., Zonneveld, J.-P., 2012. Shorefaces. In: Knaust, D., and Bromley, R.G. (Eds.), Trace Fossils as Indicators of Sedimentary Environments. Developments in Sedimentology, Elsevier, Amsterdam, 64, 563603.

Pizzi, A., 2003. Plio-Quaternary uplift rates in the outer zone of central Apennines fold-and-thrust belt, Italy. Quaternary International 101-102, 299-237.

Platt, N.H.,1989. Lacustrine carbonates and pedogenesis: sedimentology and origin of palustrine deposits from the Early Cretaceous Rupelo Formation, W Cameros Basin, N Spain. Sedimentology 36, 665-684.

Platt, N.H., Wright, V.P., 1992. Palustrine carbonates and the Florida Everglades: Towards an exposure index for the fresh-water environment? Journal of Sedimentary Petrology 62, 10581071.

Plint, A.G., 1988. Sharp-based shoreface sequences and "offshore bars" in the Cardium Formation of Alberta: their relationship to relative changes in sea level. In: Wilgus, C.K., Hastings, B.S., Kendall, C.G.St.C., Posamentier, H.W., Ross, C.A., Van Wagoner, J.C. (Eds), Sea Level Changes-An Integrated Approach. SEPM, Tulsa, pp. 357-370.

Plint, A.G., Nummedal, D., 2000. The falling stage systems tract: recognition and importance in sequence stratigraphy analysis. In: Hunt, D., Gawthorpe, R.L. (Eds.), Sedimentary Responses to Forced Regression, Geol. Soc. London Spec. Publ. 172, 1-17.

Primavera, M., Simone, O., Fiorentino, G., Caldara, M., 2011. The palaeoenvironmental study of the Alimini Piccolo lake enables a reconstruction of Holocene sea-level changes in southeast Italy. The Holocene 21, 553-563.

Ragaini, L., Cantalamessa, G., Di Celma, C., Didaskalou, P., Impiccini, R., Lori, P., Marino, M., Potetti, M., Ragazzini, S., 2006. First Emilian record of the boreal-affinity bivalve Portlandia impressa Perri, 1975 from Montefiore dell'Aso (Marche, Italy). Bollettino della Società Paleontologica Italiana 45, 227-234. 
Raychaudhuri, I., Brekke, H.G., Pemberton, S.G., MacEachern, J.A., 1992. Depositional facies and trace fossils of a low wave energy shoreface succession, Albian Viking Formation, Chigwell Field, Alberta, Canada. In: Pemberton, S.G. (Ed.), Applications of ichnology to petroleum exploration: a core workshop. SEPM Core Workshop 17, 319-328.

Reuter, M., Piller, W.E., Harzhauser, M., Kroh, A., Berning, B., 2009. A fossil Everglades-type marl prairie and its paleoenvironmental significance. Palaios 24, 747-755.

Ricci Lucchi, F., 1986. The Oligocene to Recent foreland basins in the northern Apennines. In: Allen, P.A., Homewood, P. (Eds.), Foreland Basins, Int. Assoc. Sedimentol. Spec. Publ. 8, 105-139.

Rio, D., Channell, J.E.T., Massari, F., Poli, M.S., Sgavetti, M., D’Alessandro, A., Prosser, G., 1996. Reading Pleistocene eustasy in a tectonically active siliciclastic shelf setting (Crotone peninsula, southern Italy). Geology 24, 743-746.

Saito, Y., 1994. Shelf sequence and characteristic bounding surfaces in a wave-dominated setting: Latest Pleistocene-Holocene examples from Northeast Japan. Marine Geology 120, 105-127. Saul, G.S., Naish, T.R., Abbott, S.T., Carter, R.M., 1999. Sedimentary cyclicity in the marine Pliocene-Pleistocene of the Wanganui basin (New Zealand): Sequence stratigraphic motifs characteristic of the past 2.5 m.y. Geological Society of America Bulletin 111, 524-537.

Savrda, C.E., Locklair, R.E., Hall, J.K., Sadler, M.T., Smith, M.W., Warren, J.D., 1998. Ichnofabrics, ichnocoenoses, and ichnofacies implications of an Upper Cretaceous tidal-inlet sequence (Eutaw Formation, central Alabama). Ichnos 6, 53-74.

Scrocca, D., 2006. Thrust front segmentation induced by differential slab retreat in the Apennines (Italy). Terra Nova 18, 154-161.

Seike, K., Yanagishima, S., Nara, M., Sasaki, T., 2011. Large Macaronichnus in modern shoreface sediments: Identification of the producer, the mode of formation, and paleoenvironmental implications. Palaeogeography, Palaeoclimatology, Palaeoecology 311, 224-229.

Siegenthaler, C., Huggenberger, P., 1993. Pleistocene Rhine gravel: deposits of a braided river system with dominant pool preservation. In: Best, J., Bristow, C. (Eds.), Braided Rivers. Geol. Soc. Spec. Publ., vol. 75, pp.147-162.

Smith, N.D., 1974. Sedimentology and bar formation in the upper Kicking Horse River, a braided outwash stream. Journal of Geology 82, 205-224.

Smith, N.D., Cross, T.A., Dufficy, J.P., Clough, S.R., 1989. Anatomy of an avulsion. Sedimentology $36,1-24$.

Suarez-Gonzalez, P., Quijada, I.E., Benito, M.I., Mas, J.R., 2015. Sedimentology of ancient coastal wetlands: insights from a Cretaceous multifaceted depositional system. Journal of Sedimentary Research 85, 95-117. 
Surlyk, F., Noe-Nygaard, N., 1986. Hummocky cross-stratification from the Lower Jurassic Hasle Formation of Bornholm, Denmark. Sedimentary Geology 46, 259-273.

Swift, D.J.P., 1968. Coastal erosion and transgressive stratigraphy. Journal of Geology 76, 444-456.

Swift, D.J.P., Phillips, S., Thorne, J.A., 1991. Sedimentation on continental margins, V: parasequences. In: Swift, D.J.P., Oertel, G.F., Tillman, R.W., Thorne, J.A. (Eds.), Shelf Sand and Sandstone Bodies. Int. Assoc. Sedimentol. Spec. Publ. 14, 153-187.

Tandon, S.K., Gibling, M.R., 1997. Calcretes at sequence boundaries in Upper Carboniferous cyclothems of the Sydney Basin, Atlantic Canada. Sedimentary Geology 112, 43-67.

Tanner, L.H., 2010. Continental carbonates as indicators of paleoclimate. In: Alonso-Zarza, A.M., Tanner, L.H. (Eds.), Carbonates in Continental Settings: Geochemistry, Diagenesis and Applications. Developments in Sedimentology, 62, 179-214. Elsevier, Amsterdam.

Taylor, A.M., Goldring, R., 1993.: Description and analysis of bioturbation and ichnofabrics. Journal of the Geological Society of London 150, 141-148.

Tinterri, R., Lipparini, L., 2013. Seismo-stratigraphic study of the Plio-Pleistocene foredeep deposits of the Central Adriatic Sea (Italy): Geometry and characteristics of deep-water channels and sediment waves. Marine and Petroleum Geology 42, 30-49.

Walker, R.G., Bergman, K.M., 1993. Shannon Sandstones in Wyoming: a shelf-ridge complex reinterpreted as lowstand shoreface deposits. Journal of Sedimentary Petrology 63, 839-851.

Walker and Plint, 1992. Wave- and storm-dominated shallow marine systems., In: Walker R.G., James, N.P. (Eds.), Facies models-response to sea-level changes: St. John’s, Newfoundland, Canada, Geological Association of Canada, p. 219-238.

Zecchin, M., Catuneanu, O., 2013. High-resolution sequence stratigraphy of clastic shelves I: Units and bounding surfaces. Marine and Petroleum Geology 39, 1-25.

Zecchin, M., Catuneanu, O., 2015. High-resolution sequence stratigraphy of clastic shelves III: Applications to reservoir geology. Marine and Petroleum Geology 62, 161-175.

Zecchin, M., Civile, D., Caffau, M., Sturiale, G., Roda, C., 2011. Sequence stratigraphy in the context of rapid regional uplift and high-amplitude glacio-eustatic changes: the Pleistocene Cutro Terrace (Calabria, southern Italy). Sedimentology 58, 442-477. 


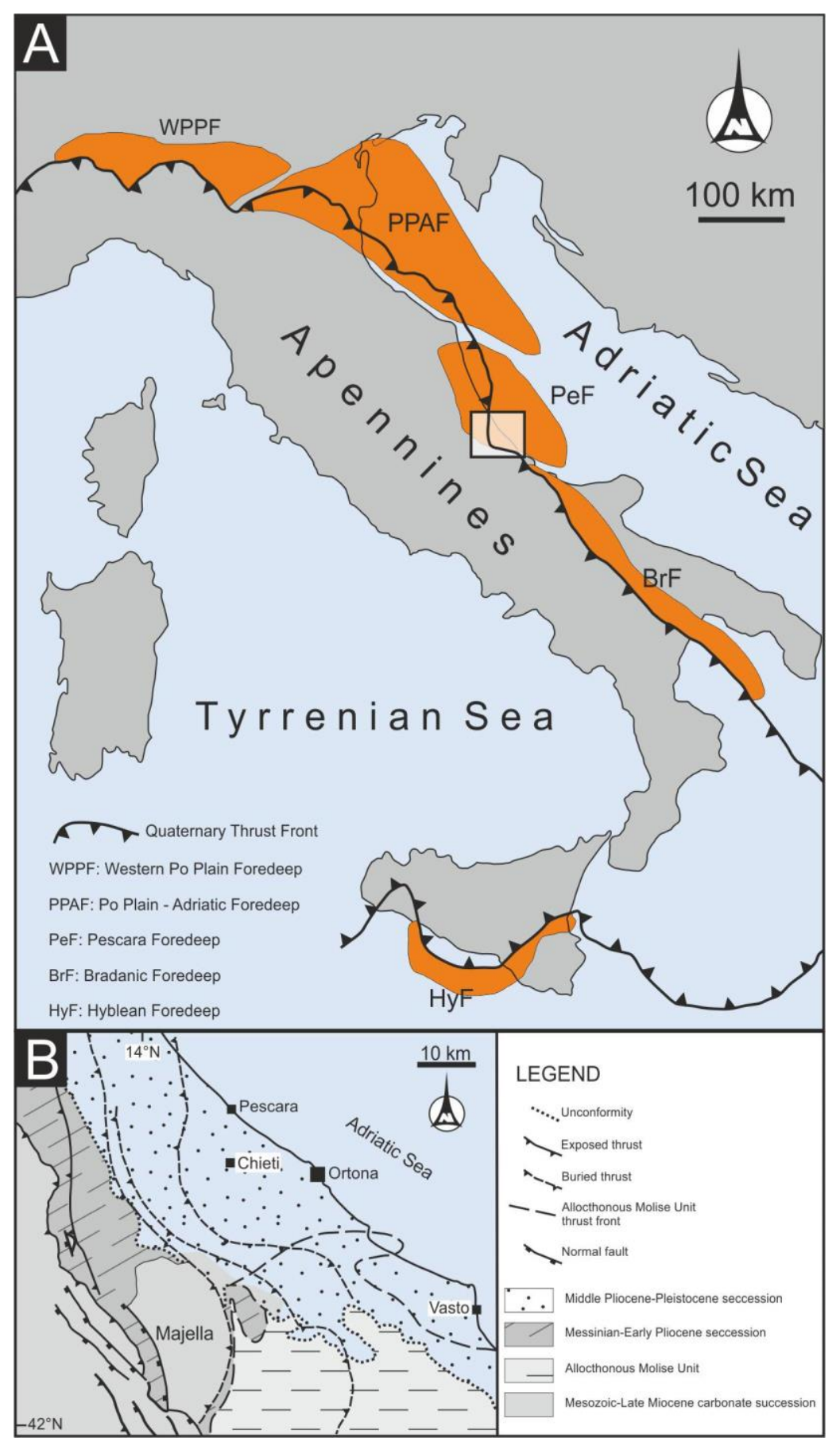




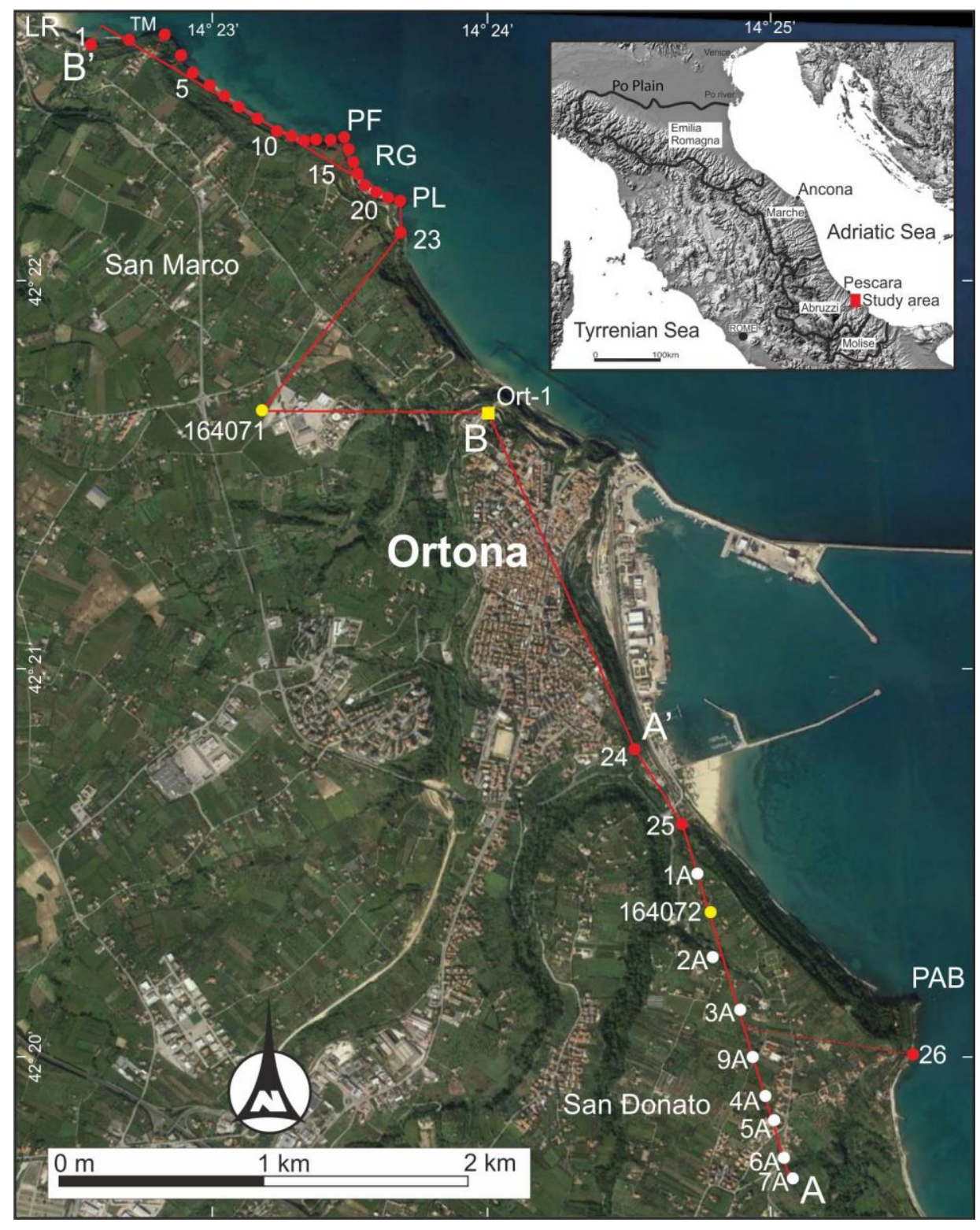




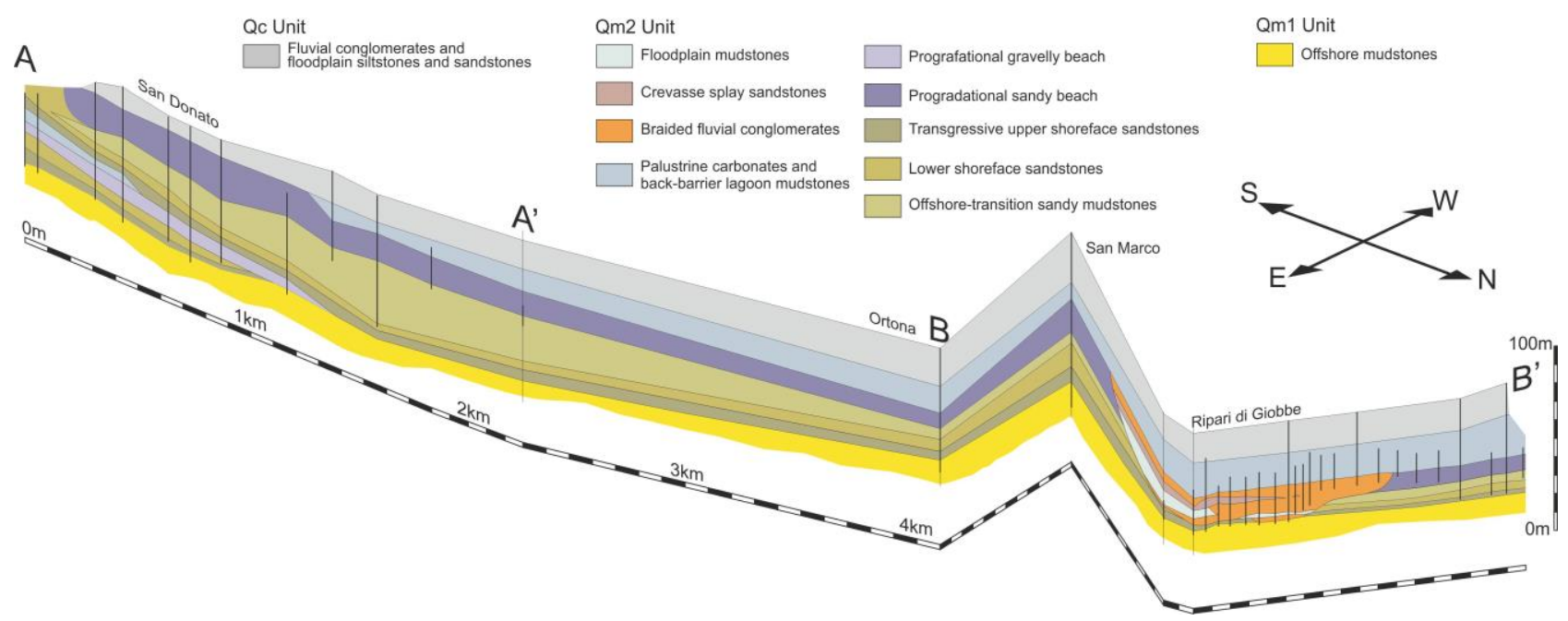



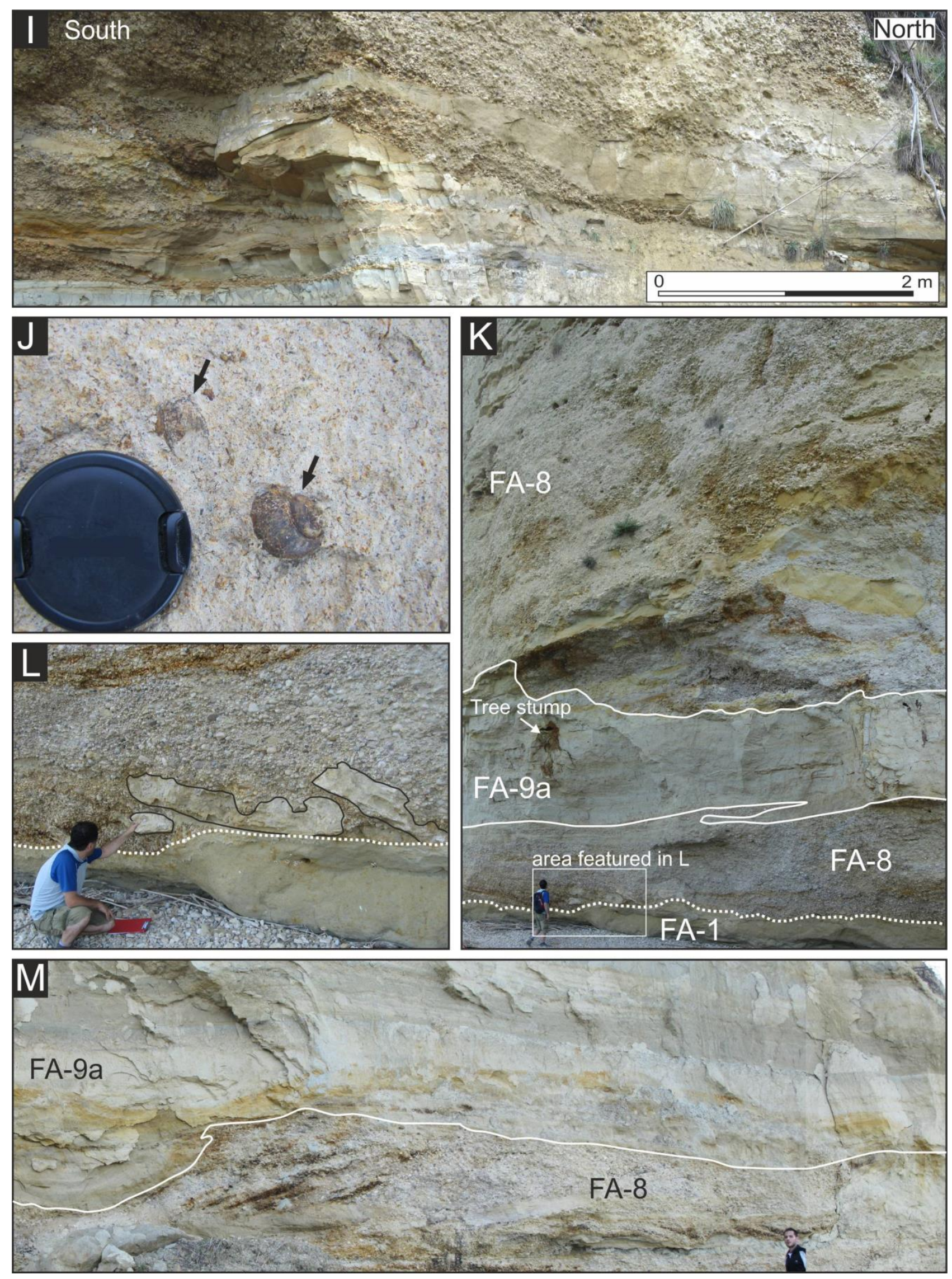

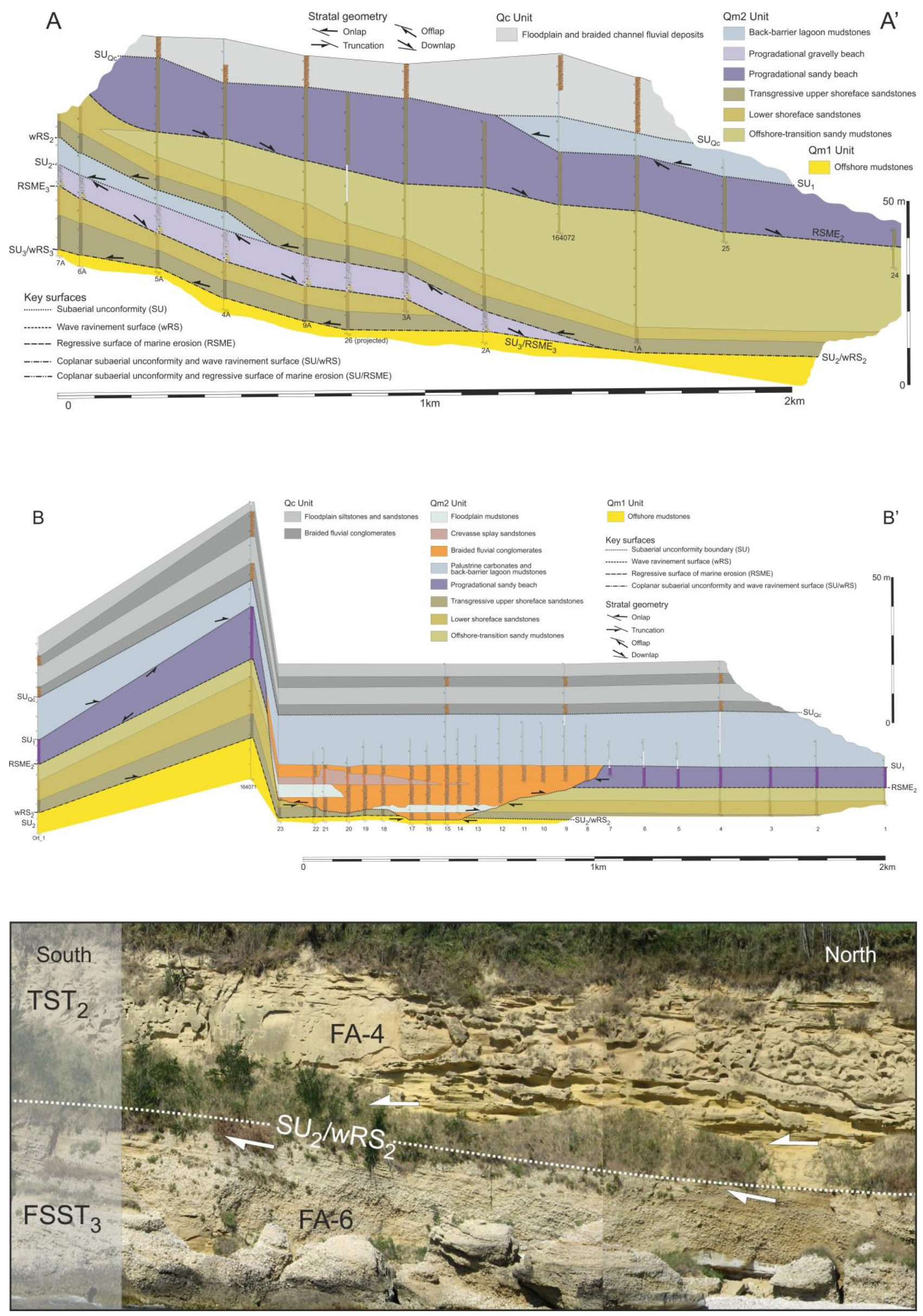


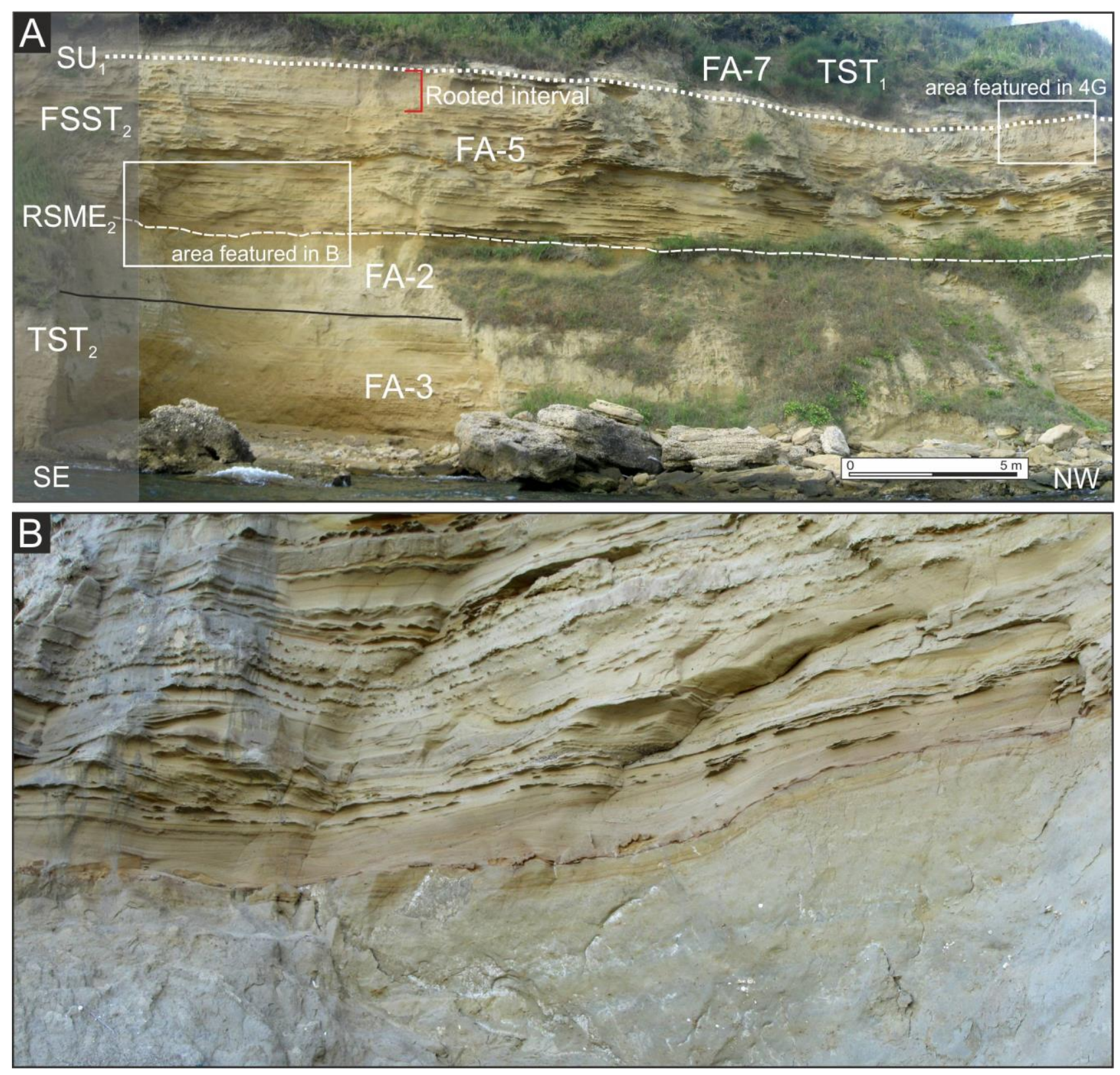



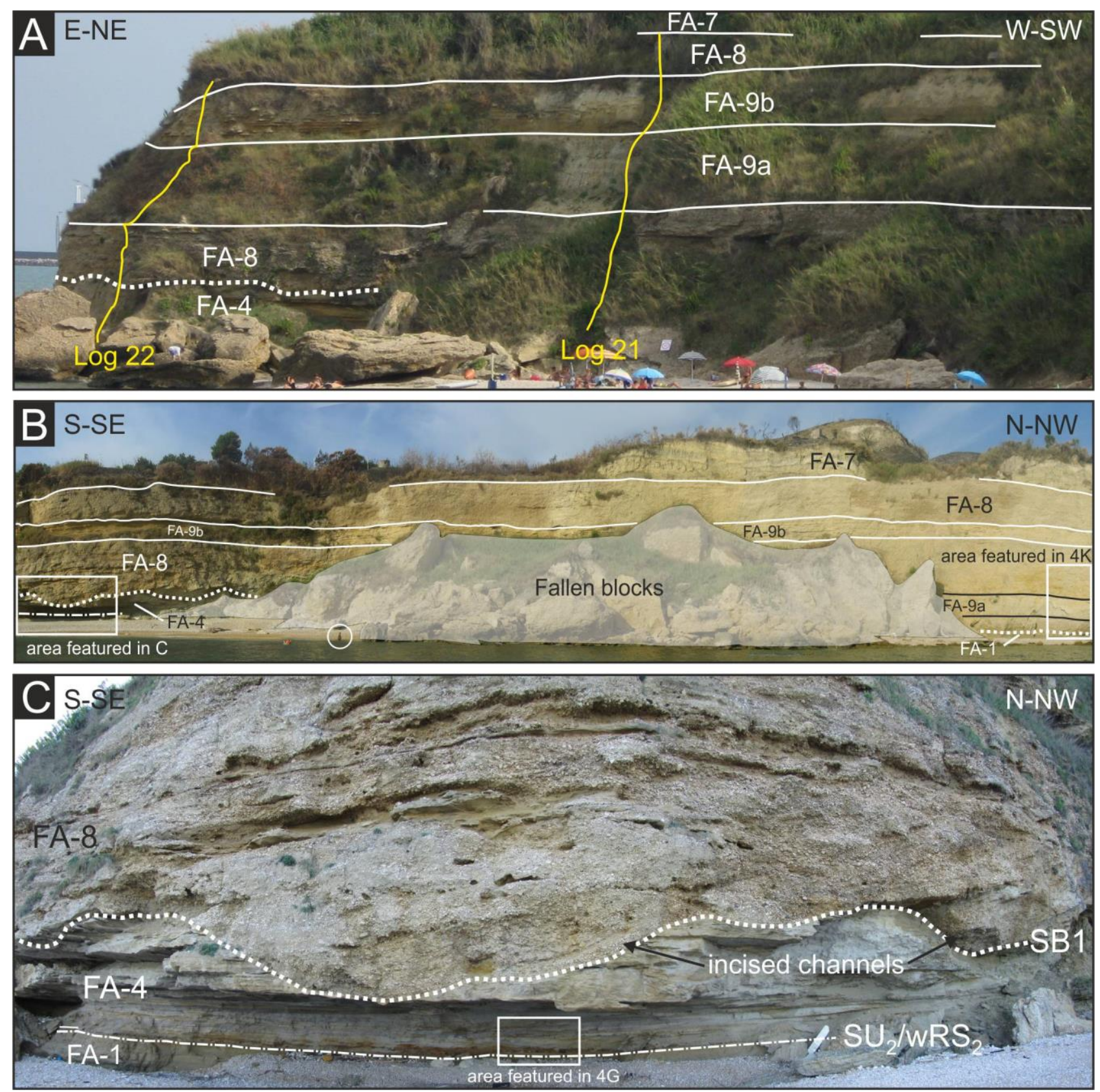


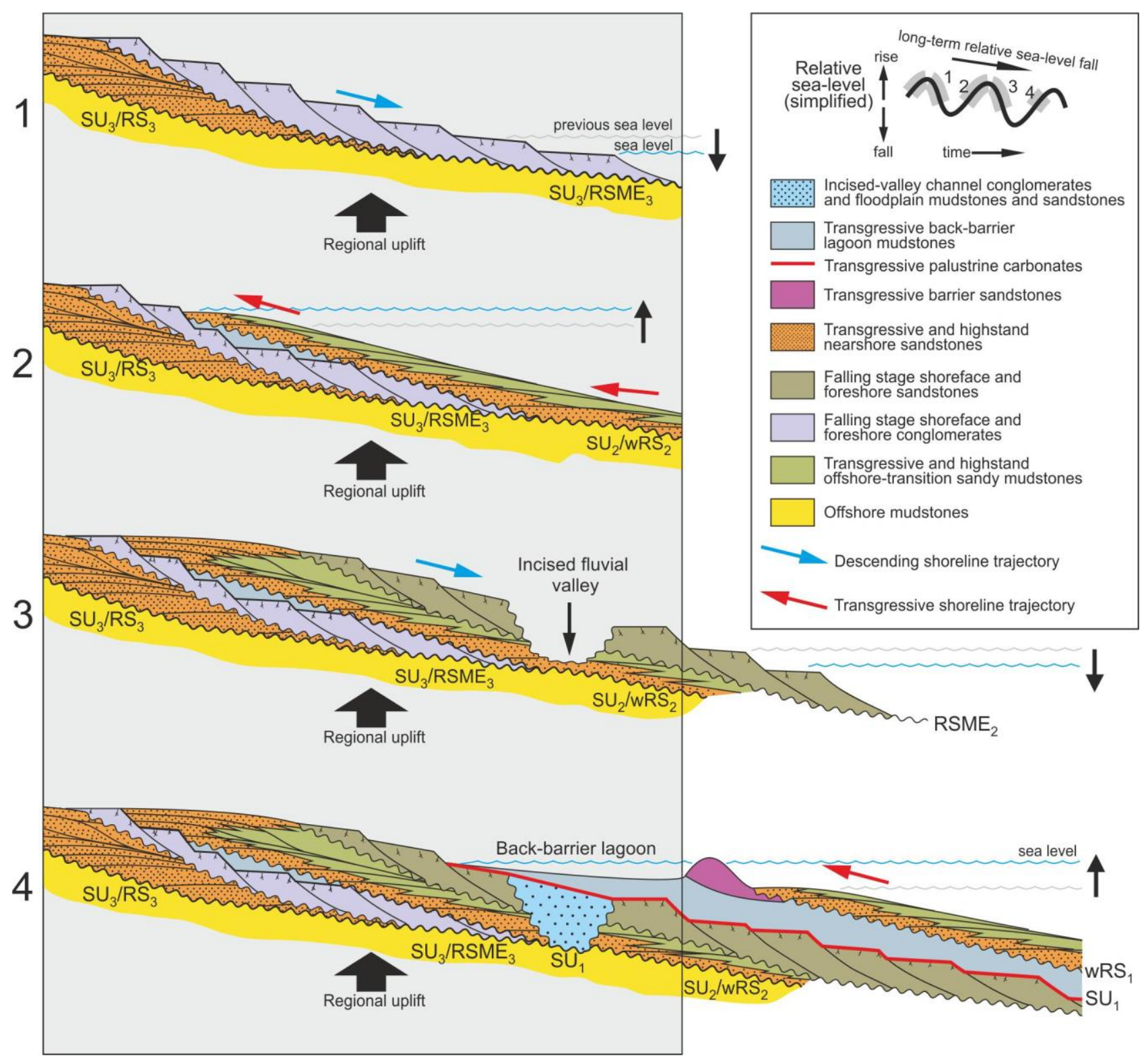

